\title{
Taxonomy of Echinostoma revolutum and 37-Collar- Spined Echinostoma spp.: A Historical Review
}

\author{
Jong-Yil Chai ${ }^{1,2, *}$ () Jaeeun Cho', Taehee Chang', Bong-Kwang Jung ${ }^{1}$, Woon-Mok Sohn ${ }^{3}$ \\ 1/nstitute of Parasitic Diseases, Korea Association of Health Promotion, Seoul 07649, Korea; ${ }^{2}$ Department of Tropical Medicine and Parasitology, \\ Seoul National University College of Medicine, Seoul 03080, Korea; ${ }^{3}$ Department of Parasitology and Tropical Medicine, and Institute of Health \\ Sciences, Gyeongsang National University College of Medicine, Jinju 52727, Korea
}

\begin{abstract}
Echinostoma flukes armed with 37 collar spines on their head collar are called as 37-collar-spined Echinostoma spp. (group) or 'Echinostoma revolutum group'. At least 56 nominal species have been described in this group. However, many of them were morphologically close to and difficult to distinguish from the other, thus synonymized with the others. However, some of the synonymies were disagreed by other researchers, and taxonomic debates have been continued. Fortunately, recent development of molecular techniques, in particular, sequencing of the mitochondrial (nad1 and cox1) and nuclear genes (ITS region; ITS1-5.8S-ITS2), has enabled us to obtain highly useful data on phylogenetic relationships of these 37-collar-spined Echinostoma spp. Thus, 16 different species are currently acknowledged to be valid worldwide, which include E. revolutum, E. bolschewense, E. caproni, E. cinetorchis, E. deserticum, E. lindoense, E. luisreyi, E. mekongi, E. miyagawai, E. nasincovae, E. novaezealandense, E. paraensei, E. paraulum, E. robustum, E. trivolvis, and Echinostoma sp. IG of Georgieva et al., 2013. The validity of the other 10 species is retained until further evaluation, including molecular analyses; E. acuticauda, E. barbosai, E. chloephagae, E. echinatum, E. jurini, E. nudicaudatum, E. parvocirrus, E. pinnicaudatum, E. ralli, and E. rodriguesi. In this review, the history of discovery and taxonomic debates on these 26 valid or validity-retained species are briefly reviewed.
\end{abstract}

Key words: Echinostoma, Echinostoma revolutum, 'revolutum' group, 37-collar-spined echinostome, historical review

\section{INTRODUCTION}

Echinostomes, including families Echinostomatidae, Himasthlidae, and Echinochasmidae, are a large group of trematodes parasitizing the small intestines of fish, reptiles, birds, and mammals [1]. Among the Echinostomatidae, Echinostoma is the most important genus in public health as well as veterinary medical aspects. The type species of the genus Echinostoma is E. revolutum (Froelich, 1802) Dietz, 1909, and within this genus numerous species have been described from birds and mammals [2,3]. At least 120 species were listed by Yamaguti [1] until the 1960s which included 101 species infecting birds and 22 species infecting mammals; among them 3 species were reported from both mammals and birds [1]. Later, a lot of new species have been described from various parts of the

\footnotetext{
- Received 6 July 2020, revised 29 July 2020, accepted 29 July 2020.

*Corresponding author (cjy@snu.ac.kr)

(C) 2020, Korean Society for Parasitology and Tropical Medicine

This is an Open Access article distributed under the terms of the Creative Commons

Attribution Non-Commercial License (https://creativecommons.org/licenses/by-nc/4.0) which permits unrestricted non-commercial use, distribution, and reproduction in any

medium, provided the original work is properly cited.
}

world. However, host specificity of many species was further studied and redefined, and many of them were synonymized with the others [4-6].

E. revolutum and other 37-collar-spined Echinostoma spp. are a large group of echinostomes representing the Echinostomatidae in various aspects. They are also called as 37-collar-spined Echinostoma spp. (group), 'E. revolutum group' [4,7], or simply 'revolutum' group [8-11]. Kanev [4] proposed that "worms with 37 collar spines belonging to the genus Echinostoma and occurring in naturally infected birds in Europe and Asia be referred to as 'E. revolutum group'. However, in the present review, for comprehensiveness and convenience, all 37-collar-spined Echinostoma spp. ever reported from naturally infected birds and/ or mammals around the world have been assigned as '37-collar-spined Echinostoma spp.' or 'E. revolutum group'.

More than 56 nominal species have been described in this group (Tables 1, 2). However, there have long been debates on the taxonomy and classification of these species. More than a half of them have been synonymized with the others (Table 2). At present, 16 species (14 of them have molecular data) (Figs. $1,2)$ are regarded as valid species, and 10 should be further 
Table 1. List of 16 valid and 10 validity-retained species of 37-collar-spined Echinostoma group

\begin{tabular}{|c|c|c|c|c|c|}
\hline Species and nominator & Size of adults (mm) & Size of eggs $(\mu \mathrm{m})$ & $\begin{array}{l}\text { Country of first } \\
\text { report }\end{array}$ & $\begin{array}{c}\text { Reference } \\
\text { no. }\end{array}$ & Validity \\
\hline E. revolutum (Froelich, 1802) Dietz, 1909 & $9.5-11.8 \times 1.5-2.1$ & $108-125 \times 57-75$ & Germany & [11] & valid (type species) \\
\hline E. acuticauda Nicoll, 1914 & $9.0-12.0 \times 0.9-1.0$ & $112-126 \times 63-75$ & Australia & [93] & retained \\
\hline E. barbosai Lie \& Basch, 1966 & $3.6-7.8 \times 0.46-0.96$ & $111-131 \times 62-66$ & Brazil & [117] & retained \\
\hline E. bolschewense (Kotova, 1939) Nasincova, 1991 & $7.4-12.5 \times 0.99-1.6$ & $138-162 \times 75-85$ & Russia & [122] & valid \\
\hline E. caproni Richard, 1964 & $5.7 \times 1.5($ av.) & $105-120 \times 50-60$ & Madagascar & {$[80]$} & valid \\
\hline E. chloephagae Sutton \& Lunaschi, 1980 & $5.1-6.9 \times 0.82-0.99$ & $100-120 \times 60-70$ & Argentina & [131] & retained \\
\hline E. cinetorchis Ando \& Ozaki, 1923 & $9.5-14.6 \times 1.7-2.2$ & $96-100 \times 61-70$ & Japan & [59] & valid \\
\hline E. deserticum Kechemir et al., 2002 & $5.6-15.2 \times 0.75-3.1$ & $58-74 \times 36-46$ & Niger & [43] & valid \\
\hline E. echinatum (Zeder, 1803) de Blainville, 1828 & $8.1-11.1 \times 0.77-1.5$ & $?$ & Germany & [99] & retained \\
\hline E. jurini (Skvortsov, 1924) Kanev, 1985 & $6.6-14.0 \times 0.58-1.3$ & $96-132 \times 72-88$ & Russia & [5] & retained \\
\hline E. lindoense Sandground \& Bonne, 1940 & $13.0-15.0 \times 2.5-3.0$ & $92-124 \times 65-76$ & Indonesia & [63] & valid \\
\hline E. luisreyi Maldonado et al., 2003 & $5.3-9.3 \times 1.1-2.3$ & $89-113 \times 65-82$ & Brazil & [44] & valid \\
\hline E. mekongi Cho et al., 2020 & $9.0-13.1 \times 1.3-2.5$ & $98-132 \times 62-90$ & Cambodia & [49] & valid \\
\hline E. miyagawai Ishii, 1932 & $9.2-11.0 \times 1.2-1.5$ & $94-96 \times 59-60$ & Japan & [11] & valid \\
\hline E. nasincovae Georgieva et al., 2014 & $4.3-4.8 \times 0.99-1.1$ & $100-105 \times 61-70$ & Czech Republic & [11] & valid \\
\hline E. novaezealandense Georgieva et al., 2017 & $9.6-10.5 \times 0.7-1.1$ & $81-87 \times 42-53$ & New Zealand & [24] & valid \\
\hline E. nudicaudatum Nasir, 1960 & $6.8-7.6 \times 0.98-1.3$ & $97-115 \times 67-72$ & UK & [171] & retained \\
\hline E. paraensei Lie \& Basch, 1967 & $7.5-16.0 \times 0.79-2.0$ & $104-122 \times 74-86$ & Brazil & [176] & valid \\
\hline E. paraulum Dietz, 1909 & $5.6-6.9 \times 1.2-1.7$ & $104-122 \times 53-70$ & Austria/Russia & {$[11]$} & valid \\
\hline E. parvocirrus Nassi \& Dupouy, 1988 & $6.7-8.4 \times 1.3-1.5$ & $105-120 \times 64-71$ & Guadeloupe & [38] & retained \\
\hline E. pinnicaudatum Nasir, 1961 & $5.5-7.1 \times 0.8-1.1$ & $97-115 \times 67-72$ & UK & [174] & retained \\
\hline E. ralli Yamaguti, 1934 & $8.6 \times 1.1(\mathrm{av})$. & $110-130 \times 68-81$ & Japan & [68] & retained \\
\hline E. robustum Yamaguti, 1935 & $7.8-9.8 \times 1.3-2.2$ & $111-129 \times 60-69$ & Taiwan & [187] & valid \\
\hline E. rodriguesi Hsu et al., 1968 & $3.9-6.8 \times 0.5-1.3$ & $96-128 \times 56-68$ & Brazil & {$[37]$} & retained \\
\hline E. trivolvis (Cort, 1914) Kanev, 1985 & $5.5-21.0 \times 0.5-1.5$ & $90-130 \times 60-70$ & USA & {$[6]$} & valid \\
\hline Echinostoma sp. IG Georgieva et al., 2013 & - & - & Germany & [45] & valid $^{a}$ \\
\hline
\end{tabular}

${ }^{a}$ validity acknowledged based on molecular and morphological data of cercariae, but description of adult worms needed.

evaluated for their validity (Table 1). Among them, zoonotic species infecting humans are at least 8 , including E. revolutum, E. cinetorchis, E. echinatum (needs confirmation), E. lindoense, E. mekongi, E. miyagawai (experimental), E. paraensei (from the coprolite of a human mummy), and E. paraulum [2,3,5,12-15]. In this review, the historical aspects and current status of 26 valid or validity-retained species of 37-collar-spined Echinostoma group are briefly reviewed.

\section{BRIEF HISTORY}

After revision and set-up new systematics of echinostomes in the early 1900s by Dietz [16,17], hundreds of articles have dealt with taxonomy and biology of echinostomes [18]. Among the workers, Beaver [19] was the one who extensively studied and reviewed the taxonomy of 37-collar-spined echinostomes. He obtained adult flukes from experimentally infected birds and mammals originating from the freshwater snail Helisoma trivolvis and described the worm as E. revolutum in USA (later turned out to be Echinostoma trivolvis by Kanev et al. [6]) and morphologically compared this species with previously reported species from the world. He synonymized 9 species with E. revolutum, including Echinostoma armigerum Barker \& Irvine, 1915, Echinostoma cinetorchis Ando \& Ozaki, 1923, Echinostoma coalitum Barker \& Beaver, 1915, Echinostoma columbae Zunker, 1925, Echinostoma echinatum (Zeder, 1803) de Blainville, 1828, Echinostoma limicoli Johnson, 1920, Echinostoma miyagawai Ishii, 1932, Echinostoma mendax Dietz, 1909, and Echinostoma paraulum Dietz, 1909. In addition, he treated 11 species as synonyms inquirenda, which included Echinostoma acuticauda Nicoll, 1914, Echinostomas armatum (Molin, 1850) Yamaguti, 1971, Echinostoma callawayensis Barker \& Noll, 1915, Echinostoma dilatatum (Miram, 1840) Cobbold, 1960, Echinostoma echinocephalum (Rudolphi, 1819) Cobbold, 1860, Echinostoma erraticum Lutz, 1924, Echinostoma microrchis Lutz, 1924, Echinostoma neglectum Lutz, 1924, Echinostoma nephrocystis Lutz, 1924, Echinostoma oxycephalum (Rudolphi, 1819) Railliet, 1896, and Echinostoma sudanense Odhner, 1911. Later, 
Table 2. List of 37-collar-spined Echinostoma spp. (30 species) synonymized with other species

\begin{tabular}{|c|c|c|c|}
\hline Species and nominator & Country of first report & Synonymized with & Synonymy proposed by \\
\hline E. armatum (Mollin, 1858) Yamaguti, 1971 & South America & E. revolutum & Beaver [19] \\
\hline E. armigerum Barker and Irvine, 1915 & North America & E. trivolvis & Kanev $[4,20]$ \\
\hline E. audyi Lie and Umathevy, 1965 & Malaysia & E. revolutum & Kanev [20] \\
\hline E. callawayensis Barker and Noll, 1915 & North America & E. trivolvis & Kanev $[4,20]$ \\
\hline E. coalitum Barker and Beaver, 1915 & North America & E. trivolvis & Kanev $[4,20]$ \\
\hline E. columbae Zunker, 1925 & Germany & E. revolutum & Beaver [19] \\
\hline Echinoparyphium contiguum Barker and Bastron, 1915 & USA & E. trivolvis & Kanev et al. [6] \\
\hline E. dilatatum (Miram, 1840) Cobbold, 1860 & Russia & E. revolutum & Beaver [19] \\
\hline E. equinatus gigas Marco del Pont, 1926 & Argentina & $\begin{array}{l}\text { Echinoparyphium } \\
\text { recurvatum }\end{array}$ & Lunaschi et al. [29] \\
\hline E. echinocephalum (Rudolphi, 1819) Cobbold, 1860 & Egypt & E. revolutum & Beaver [19] \\
\hline E. erraticum Lutz, 1924 & Brazil & E. revolutum & Beaver [19] \\
\hline E. friedi Toledo et al., 2000 & Spain & E. miyagawai & Faltýnková et al. [11] \\
\hline E. ivaniosi Mohandas, 1973 & India & E. revolutum & Kanev [4] \\
\hline E. liei Jeyarasasingam et al., 1972 & Egypt & E. caproni & Huffman and Fried [7] \\
\hline E. limicoli Johnson, 1920 & Europe & E. revolutum & Beaver [19] \\
\hline E. Iondonensis Khan, 1961 & UK & E. jurini & Kanev [4] \\
\hline E. mendax Dietz, 1909 & Brazil & E. revolutum & Beaver [19] \\
\hline E. microrchis Lutz, 1924 & Brazil & E. revolutum & Beaver [19] \\
\hline E. multispinosum Pérez Vigueras, 1944 & Cuba & E. trivolvis & Kanev et al. [6] \\
\hline E. neglectum Lutz, 1924 & Brazil & E. revolutum & Beaver [19] \\
\hline E. nephrocystis Lutz, 1924 & Brazil & E. revolutum & Beaver [19] \\
\hline E. orlovi Romashov, 1966 & Russia & E. jurini & Kanev et al. [5] \\
\hline E. oxycephalum (Rudolphi, 1819) Railliet, 1896 & Europe & E. revolutum & Beaver [19] \\
\hline E. revolutum tenuicollis Bashikirova, 1941 & Azerbaidzhan & E. revolutum & This review \\
\hline E. revolutum var. japonicum Kurisu, 1932 & Japan & E. revolutum & Yamaguti [1] \\
\hline E. sisjakowi (Skvortsov, 1935) Yamaguti, $1971^{\mathrm{a}}$ & Russia & E. jurini & Kanev et al. [5] \\
\hline E. spiniferum (La Valette, 1855) sensu Nasincova, 1992 & Czechoslovakia & E. nasincovae & Faltýnková et al. [11] \\
\hline E. stromi Bashkirova, 1946 & Azerbaidzhan & E. revolutum & Yamaguti [1] \\
\hline E. sudanense Odhner, 1910 & Sudan & E. revolutum & Beaver [19] \\
\hline E. togoensis Jourdan and Kulo, 1981 & Togo & E. caproni & Huffman and Fried [7] \\
\hline
\end{tabular}

aformerly Echinoparyphium sisjakowi Skvortsov, 1935.

however, some of these species, including E. revolutum of Beaver [19], E. armigerum, E. coalitum, and E. callawayensis, were synonymized with Echinostoma trivolvis (Cort, 1914) Kanev, 1985 [6,20]. Kanev et al. [6] also synonymized Echinostoma multispinosum Pérez Vigueras, 1944, E. paraulum of Miller, 1937, and Echinoparyphium contiguum Barker \& Bastron, 1915 with E. trivolvis. However, the validity of E. miyagawai, E. cinetorchis, and E. paraulum were re-evaluated and acknowledged by Kostadinova et al. [21], Chai [3,22], and Georgieva et al. [10], respectively. The morphologies of E. miyagawai and E. paraulum were redescribed $[11,21]$. The name E. acuticauda is still used by other researchers $[23,24]$, although this species needs re-evaluation. The 4 species of 37-collar-spined Echinostoma from Brazil, including E. erraticum, E. microrchis, E. neglectum, and E. nephrocystis, and 2 non-37-collar-spined species, Echinostoma exile (43-45 collar spines) and Echinostoma parses- pinosum (29-33 collar spines), were re-examined and redescribed by Kohn and Fernandes [25]. Kostadinova and Gibson [26] stated that the 4 species of 37-collar-spined species redescribed by them [25] exhibited significant morphological differences suggesting their taxonomic significance. In addition, a checklist of cercariae in molluscs from Brazil listed the names of E. erraticum (infecting Spirulina and Drepanotrema snails) and E. nephrocystis (infecting Physa sp. snails) [27]. However, in the present review, these 4 species were tentatively regarded as synonyms of E. revolutum, as suggested by Beaver [19].

Echinostoma equinatus gigas Marco del Pont, 1926 [28] was reported from Argentina, but the worms were later assigned to Echinoparyphium recurvatum by Lunaschi et al. [29]. Echinostoma chloephagae Sutton and Lunaschi, 1980 also reported from Argentina attracted no much taxonomic attention but listed in a checklist of parasites of birds from Argentina [29]. Echinostoma 

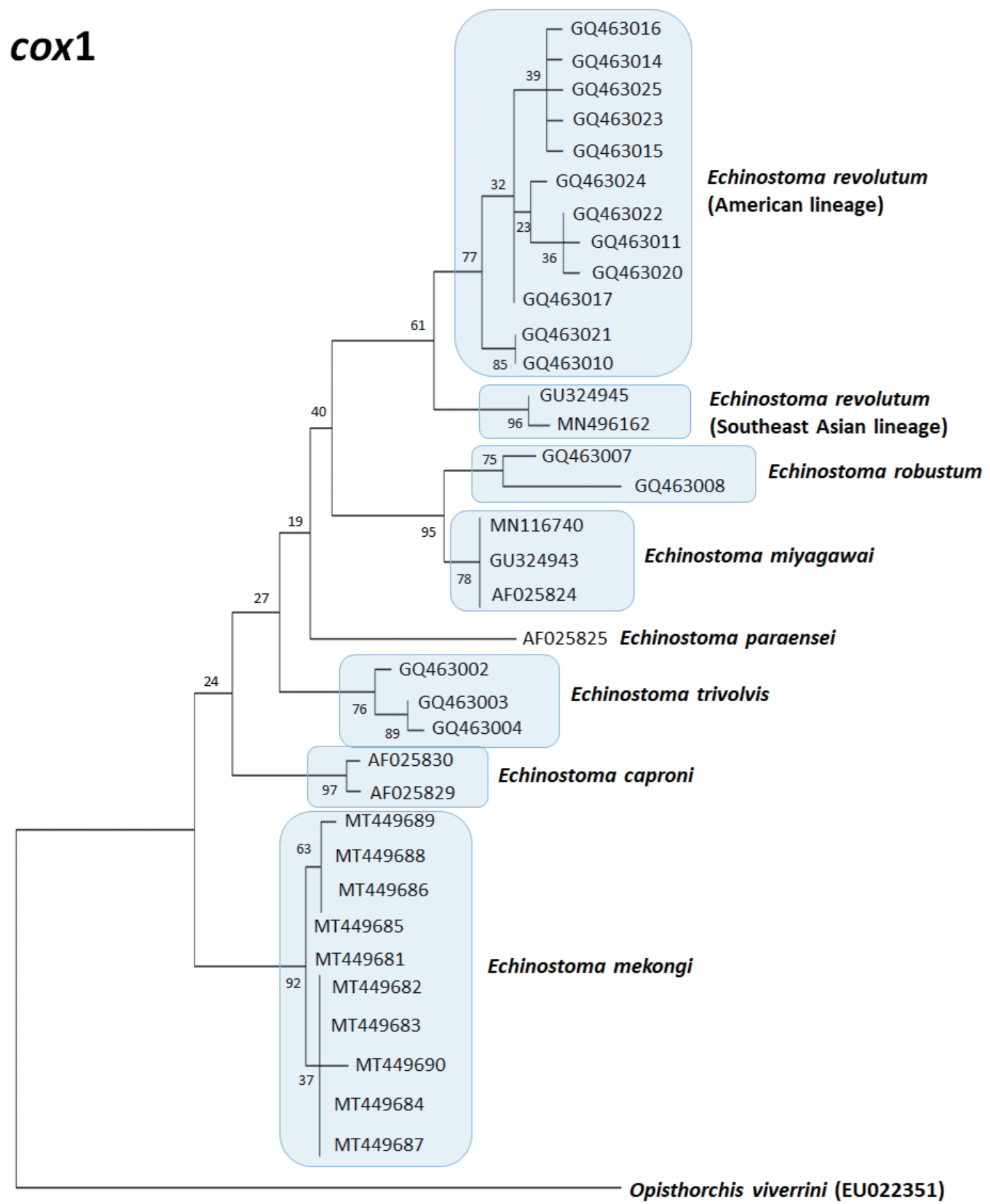

0.050

Fig. 1. A phylogenetic tree of Echinostoma revolutum (Southeast Asian and American lineages) and 6 other 37-collar-spined Echinostoma group constructed based on 184 bp of mitochondrial cox 1 sequences by maximum-likelihood method using the MEGA-X program employing Tamura-nei model of nucleotide substitution with 1,000 bootstrap replications. Opisthorchis viverrini was used as an outgroup. 


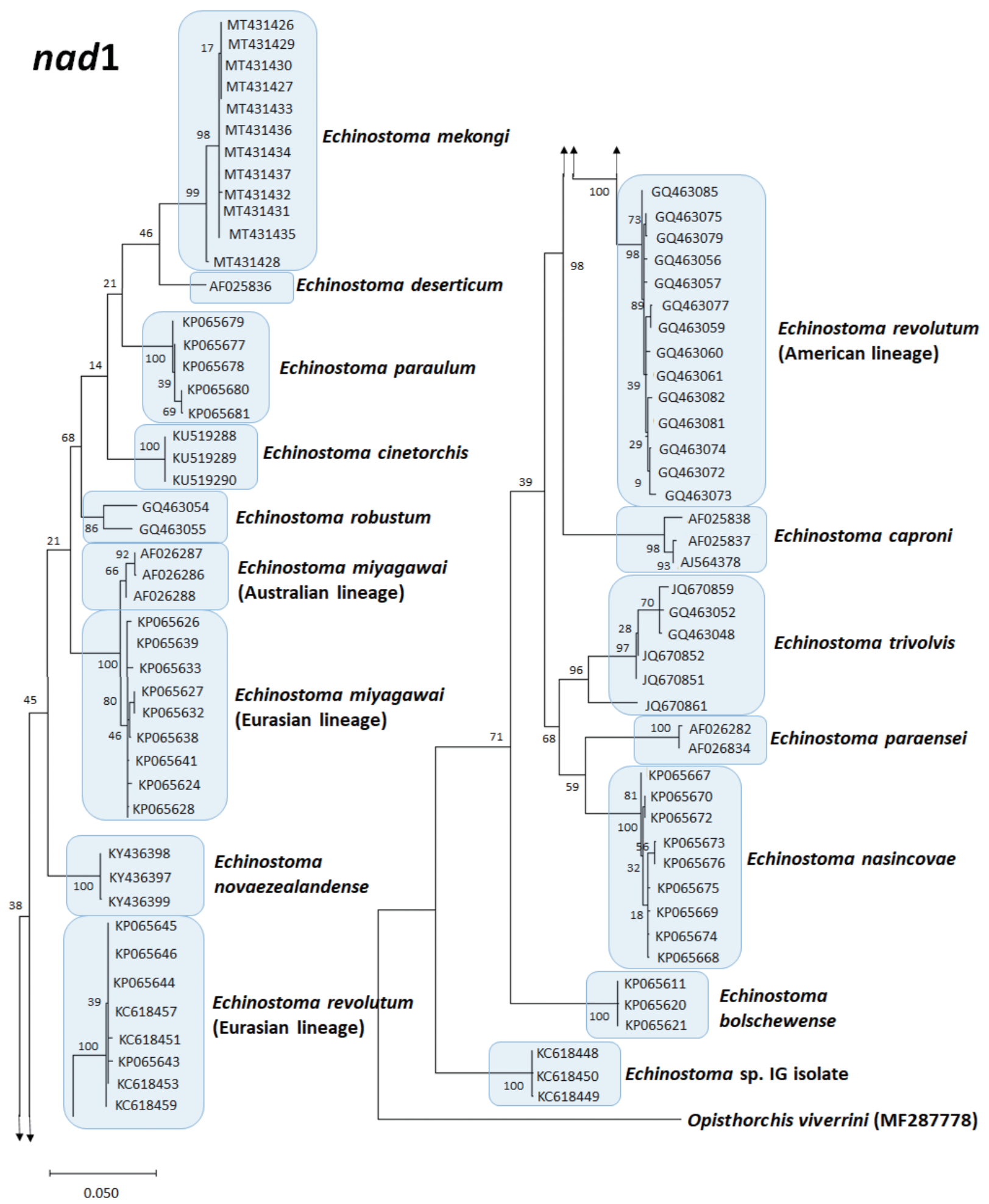

Fig. 2. A phylogenetic tree of Echinostoma revolutum (Eurasian and American lineages) and 13 other 37-collar-spined Echinostoma spp. constructed based on 472 bp of mitochondrial nad1 sequences by maximum-likelihood method using the MEGA-X program employing Tamura-nei model of nucleotide substitution with 1,000 bootstrap replications. O. viverrini was used as an outgroup. 
ralli Yamaguti, 1934 was reported in Japan and this name was used by Yoshino et al. [30]. The taxonomic validity of Echinostoma robustum Yamaguti, 1935 which was originally reported from Taiwan was supported by Detwiler et al. [31] through molecular analyses of specimens from USA and Brazil. However, the specific diagnosis of these worms as E. robustum needs reconfirmation. Echinostoma goldi Oschmarin, 1956 was reported from the intestine of the bird Pernis apivorus in Russian Far East [32]; this species was mentioned to have 37 collar spines by Yamaguti [1] but the figure presented by Skrjabin and Bashikirova [32] shows that it has 35 collar spines. Therefore, this species (species inquirenda) is excluded from the 37-collar-spined Echinostoma group until further studies are performed to confirm that it evidently has 37 collar spines.

Echinostoma revolutum var. japonicum Kurisu, 1932 and Echinostoma stromi Bashikirova, 1946 have been synonymized with E. revolutum by Yamaguti [1]. Echinostoma revolutum tenuicolle Bashikirova, 1941 seems to be a synonym of E. revolutum. Among the 3 species reported from UK, including Echinostoma nudicaudatum Nasir, 1960, Echinostoma pinnicaudatum Nasir, 1961, and Echinostoma londonensis Khan, 1961, the former 2 have seldom attracted taxonomic attention, whereas E. londonensis was suggested to be identical with E. echinatum by Kanev [4].

Kanev [4,20] studied on the life cycle of E. revolutum in Europe (from Germany) using the freshwater snail Lymnaea stagnalis as the starting point and redescribed the morphology of larval and adult E. revolutum. Kanev [4] and Kanev et al. [5,6] synonymized Echinostoma audyi Lie \& Umathevy, 1965, Echinostoma ivaniosi Mahandas, 1973, and E. paraulum Dietz, 1909 with E. revolutum. Also, Kanev [4,20], Huffman and Fried [7], and Kanev et al. [5,6,33] synonymized Echinostoma lindoense Sandground \& Bonne, 1940, Echinostoma barbosai Lie \& Basch, 1966, E. miyagawai Ishii, 1932, and E. revolutum of Nasincova, 1986 with E. echinatum. Kanev et al. [5] also synonymized Echinostoma sisjakowi (Skvortsov, 1935) Yamaguti, 1971, Echinostoma orlovi Romashov, 1966, and Echinostoma bolschewense (Kotova, 1939) Nasincova, 1991 with E. jurini (Skvortsov, 1924) Kanev, 1985. Meanwhile, Echinostoma liei Jeyarasasingam et al., 1972, Echinostoma togoensis Jourdan \& Kulo, 1981, and Echinostoma paraensei Lie \& Basch, 1967 were synonymized with Echinostoma caproni Richard, 1964 by Huffman and Fried [7]. Thus, Kanev [4] listed only 5 species in the 37-collar-spined Echinostoma group, which included E. revolutum (sensu stricto), E. trivolvis, E. caproni, E. jurini, and E. echinatum. Later, however, E. paraensei was acknowledged as a dis- tinct species because of its unique isoenzymatic patterns [34] and unique DNA sequences [35]. In addition, Kostadinova and Gibson [26] and Kostadinova et al. [21,36] reconsidered E. miyagawai as a distinct species, and rather questioned about the taxonomic status of E. echinatum.

In the meantime, Echinostoma rodriguesi Hsu et al., 1968 was reported as a new 37-collar-spined group from Brazil [37], and Echinostoma parvocirrus Nassi and Dupouy [38], 1988 from Guadeloupe, French West Indies. Echinostoma friedi Toledo et al. [39], 2000 was described as a new species in Spain. Thereby, Kostadinova et al. [26] listed 8 species in the 'revolutum' group, which included E. revolutum (sensu stricto), E. jurini, E. trivolvis, E. paraensei, E. caproni, E. miyagawai, E. parvocirrus, and E. friedi but did not include E. rodriguesi. According to Kostadinova et al. [40], a voucher specimen of E. revolutum designated by Morgan and Blair [41] from Australia was found to be affiliated to E. robustum (?) although they did not favor this specific diagnosis; later Georgieva et al. [10] assigned this isolate to $E$. miyagawai. However, the validity of E. robustum was supported by Detwiler et al. [31,42] based on materials from North America and Brazil. After then, Echinostoma deserticum Kechemir et al., 2002 was reported as a new 37-collar-spined species from Africa [43], and Echinostoma luisreyi Maldonado et al., 2003 as a new member from Brazil [44]. Fried and Graczyk [8] listed 10 species in the 37-collar-spined Echinostoma spp., including E. revolutum, E. caproni, E. echinatum, E. friedi, E. jurini, E. luisreyi, E. miyagawai, E. paraensei, E. parvocirrus, and E. trivolvis; however, they did not mention about E. deserticum, E. rodriguesi, and E. robustum. Toledo et al. [9] listed 10 species, including E. revolutum, E. caproni, E. deserticum, E. friedi, E. jurini, E. luisreyi, E. miyagawai, E. paraensei, E. parvocirrus, and E. trivolvis, but did not mention on E. echinatum, E. rodriguesi, and E. robustum.

Based on molecular, morphological, and ecological data, the classification of 37-collar-spined Echinostoma species became more diverse and have been continuously changing [10,11,24,31,42,45,46]. Faltýnková et al. [11] synonymized E. friedi with E. miyagawai based on morphological data. Mohanta et al. [46] suggested synonymy of E. robustum, E. miyagawai, and $E$. friedi, but the synonymy between E. miyagawai (E. friedi) and E. robustum is disagreed by other workers [47]. It is also noteworthy that several new cryptic 37-collar-spined Echinostoma spp. have been discovered in different parts of the world, which included Echinostoma sp. IG by Georgieva et al., 2013 [45], Echinostoma spp. clade 3 by nad1 and ITS2 analyses by 
Noikong et al. [48], Echinostoma nasincovae Georgieva et al., 2014 [10,11], Echinostoma novaezealandense Georgieva et al., 2017 [24], and Echinostoma mekongi Cho et al., 2020 [49]. Synonymies previously based only on morphological characters should be reconsidered until the results are firmly supported by molecular evidences.

\section{SPECIES REPORTED IN EACH CONTINENT}

\section{Asia}

At least 11 species, including E. revolutum [50-57], E. audyi [58], E. cinetorchis [59-61], E. ivaniosi [62], E. lindoense [63], E. mekongi [49], E. miyagawai [64,65], E. paraulum [14,66,67], E. ralli [68], E. revolutum var. japonicum [69], and E. robustum [70] were reported to have 37 collar spines. E. audyi and E. ivaniosi were synonymized with E. revolutum by Kanev [4], and E. revolutum var. japonicum with E. revolutum by Yamaguti [1]. Beaver [19] synonymized E. cinetorchis with E. revolutum; however, E. cinetorchis is characteristic in having testes which are mobile to other locations within the body; one or both testes even disappear from the body while they grow to be adults $[2,3,13,22,71]$. E. lindoense was synonymized with E. echinatum by Kanev et al. [33]; however, the status of E. echinatum is questioned by many workers $[10,11,26]$. In addition, E. lindoense has unique larval and adult morphology discriminating from $E$. revolutum (see E. lindoense section), and thus the name E. lindoense is retained in this review. E. mekongi was reported as a new species from human infections in 2 provinces of Cambodia along the Mekong River, which is morphologically close to E. revolutum and E. miyagawai but molecularly distinct from them and also 12 other 37-collar-spined Echinostoma spp. available in Gen-
Bank [49]. A recent mitochondrial DNA study reported that 2 distinct species, including E. revolutum and E. miyagawai, exist in Thailand and Lao PDR [72]. In China, complete mitochondrial genome of $E$. miragawai has been obtained and characterized [73,74]. A synonymy between E. mixagawai and E. robustum was suggested based on molecular analysis in Bangladesh [46]; however, this synonymy is disagreed by Heneberg [47]. Cytochrome B gene was found to be useful to differentiate Asian E. revolutum from African E. caproni and South American E. paraensei [75]. Thus, at least 8 species, including E. revolutum, E. cinetorchis, E. lindoense, E. mekongi, E. miyagawai, E. paraulum, E. ralli, and E. robustum, are recognized to be existing in Asia (Table 3).

\section{Europe}

More than 18 species of 37-collar-spined Echinostoma spp. were reported from European countries, including Germany, Bulgaria, UK, Austria, Czech Republic, Spain, and Russia; E. revolutum, E. bolschewense, E. columbae, E. dilatatum, E. echinatum, E. friedi, E. goldi, E. jurini, E. londonensis, E. miyagawai, E. nasincovae, E. nudicaudatum, E. orlovi, E. oxycephalum, E. paraulum, E. pinnicaudatum, E. sisjakowi, and Echinostoma sp. IG of Georgieva et al., 2013 [45]. Among them, E. columbae, E. dilatatum, and E. oxycephalum were synonymized with E. revolutum or put as species inquirenda by Beaver [19]. E. orlovi and E. sisjakowi were synonymized with E. jurini by Kanev et al. [5]. E. goldi had 35 collar spines in the figure of Skrjabin and Bashikirova [32] thus considered not a member of 37-collar-spined group. E. bolschewense and E. londonensis were synonymized with E. jurini and E. echinatum, respectively, and E. paraulum was synonymized with E. revolutum by Kanev [4] and Kanev et

Table 3. Continental distribution of 37-collar-spined Echinostoma spp.

\begin{tabular}{|c|c|c|c|c|c|}
\hline Asia & Europe & Africa & North/Central America & South America & Oceania \\
\hline E. revolutum & E. revolutum & E. caproni & E. revolutum & E. revolutum & E. revolutum \\
\hline E. cinetorchis & E. bolschewense & E. deserticum & E. parvocirrus & E. barbosai & E. acuticauda \\
\hline E. lindoense & E. echinatum & & E. robustum & E. chloephagae & E. miyagawai \\
\hline E. mekongi & E. jurini & & E. trivolvis & E. luisreyi & E. novaezealnadense \\
\hline E. miyagawai & E. miyagawai & & & E. paraensei & E. paraensei \\
\hline E. paraulum & E. nasincovae & & & E. robustum & \\
\hline E. ralli & E. nudicaudatum & & & E. rodriguesi & \\
\hline \multirow[t]{4}{*}{ E. robustum } & E. paraulum & & & & \\
\hline & E. pinnicaudatum & & & & \\
\hline & E. robustum & & & & \\
\hline & Echinostoma sp. IG & & & & \\
\hline
\end{tabular}

This table has been revised and updated from Chai (2019) [3]. 
al. [5]. However, the synonymy of E. bolschewense with E. jurini was denied because of morphological differences in their cercariae [11]. Thus, E. bolschewense was regarded as a distinct species, and the the status of E. jurini was retained [11]. In addition, E. paraulum was revalidated as distinct species $[10,11]$. On the other hand, E. friedi reported by Toledo et al. [39] was synonymized with E. miragawai by Faltýnková et al. [11]. E. robustum Yamaguti, 1935 has been acknowledged as a distinct species based on specimens harvested from a duck in UK [76]; this species was also recorded from birds in Poland [77] and Russia $[78,79]$. E. miyagawai originally reported from Japan was later reported also in Bulgaria and Czech Republic [21,36]. Put together, in Europe, at least 11 species of 37-collar-spined echinostomes can be currently acknowledged to be valid or validity-retained; E. revolutum (sensu stricto), E. bolschewense, E. echinatum, E. jurini, E. miyagawai, E. nasincovae, E. nudicaudatum, E. paraulum, E. pinnicaudatum, E. robustum, and Echinostoma sp. IG [11,76] (Table 3).

\section{Africa}

More than 5 species of 37-collar-spined Echinostoma spp. were nominally described, including E. caproni $[80,81]$, E. deserticum [43], E. revolutum [82], E. liei [83], and E. togoensis [84]. However, Kanev [4] suggested that E. revolutum described by Bisseru [82] was actually E. caproni. Fried and Huffman [85] also suggested that the studies performed under the name $E$. revolutum, E. liei, and E. togoensis using materials from Africa actually dealt with E. caproni. Thereby, only 2 species, E. caproni and E. deserticum can be currently recognizable as the 37-collar-spined Echinostoma spp. existing in Africa (Table 3).

\section{North and Central America}

The taxonomy of 37-collar-spined Echinostoma spp. in North and Central America has not yet been properly revised or settled [10]. In North America, 5 species were reported at an earlier time, including E. trivolvis, E. armigerum, E. coalitum, E. collawayensis, and Echinoparyphium contiguum $[6,10]$. Beaver [19] treated 4 of the above (E. armigerum, E. coalitum, E. collawayensis, and $E$. contiguum) as synonyms of $E$. revolutum or synonyms inquirenda. However, Kanev [20] pointed out that the E. revolutum of Beaver [19] and many articles published from North America under the name E. revolutum during 1968-1988 should be reconsidered to have been actually E. trivolvis. The true existence of $E$. revolutum in North America was later confirmed in 1997-1998 by Sorensen et al. [86,87] through morphological as well as molecular studies. Later, based on nad1 gene sequences, the American E. revolutum was shown to be genetically distinct from European populations, and further studies seemed necessary on the taxonomy of North American 37-collar-spined Echinostoma spp. [10,31]. In addition, Detwiler et al. [31] detected the presence of E. robustum from Indiana and Minnesota, USA, and also from Brazil. From Guadeloupe (French West Indies), E. parvocirrus was reported [38]. Thus, in North and Central America, at least 4 species can be listed as the 'revolutum' group; E. revolutum, E. parvocirrus, E. robustum, and E. trivolvis [38,42] (Table 3).

\section{South America}

More than 14 species, namely, E. revolutum, E. armatum, E. barbosai, E. chloephagae, E. equinatus gigas, E. erraticum, E. hiisreyi, E. mendax, E. microrchis, E. neglectum, E. nephrocystis, E. paraensei, E. robustum, and E. rodriguesi, have been described in South America [19,31,42,44,88-90]. The presence of E. revolutum in Brazil has been reported by various workers, including Brasil and Amato [91], as reviewed by Maldonado and Lanfredi [92]. E. barbosai was synonymized with E. echinatum by Kanev et al. [33]; however, the status of E. echinatum is not recognized by other workers $[10,11]$. Therefore, the name E. barbosai is retained until further confirmatory studies are performed. Beaver [19] treated the 4 species reported from Brazil by Lutz [88], i.e., E. erraticum, E. neglectum, E. microrchis, and E. nephrocystis, as synonym inquirenda. These might be identical with E. revolutum or E. trivolvis. However, Kanev et al. [6] did not recognize the presence of $E$. trivolvis in South America; although, the possible existence of E. trivolvis in South America remains to be confirmed. In the present review, the 4 species reported by Lutz [88] were tentatively synonymized with $E$. revolutum. E. equinatus gigas reported by Marco del Pont [28] was later assigned to Echinoparyphium recurvatum [29]. Kanev [20] considered E. paraensei a synonym of E. caproni, and Huffman and Fried [7] accepted this synonymy. However, E. paraensei was acknowledged as a distinct species because of its unique isoenzymatic patterns [34] and DNA sequences [35]. The presence of E. robustum in South America was first suggested by molecular analysis of materials obtained from Brazil [31]. Therefore, the existence of at least 7 species of 37-collarspined echinostomes, including E. revolutum, E. barbosai, E. chloephagae, E. huisreyi, E. paraensei, E. robustum, and E. rodrigue$s i$, is currently recognized to be valid or validity-retained in South America (Table 3). It is of considerable interest that in a 
mummified human body in Brazil, eggs presumed to be of $E$. paraensei (or E. luisreyi) were detected by a molecular technique [15].

\section{Oceania}

A total of 5 species of 37-collar-spined echinostomes have been reported; E. acuticauda, E. miyagawai, E. novaezealandense, E. paraensei, and E. revolutum (Table 1). E. acuticauda was reported in 1914 in Australia [93], and soon synonymized (synonym inquirenda) with E. revolutum by Beaver [19]. However, this synonymy is not agreed by other workers, and the name $E$. acuticauda has been used by Jones and Anderson [23] and Georgieva et al. [24]. Morgan and Blair [41] reported that 3 metacercarial isolates (LMeta-1, PMeta-1, and PMeta-2) from Townsville showed greater than $98 \%$ sequence similarity with E. revolutum from Europe. Later, Kostadinova et al. [40] suggested all these isolates to be E. robustum (?). However, Georgieva et al. [10] placed all these isolates among the clusters of E. miyagawai. Thus, the presence of E. robustum in Australia needs reconfirmation. Morgan and Blair [41] also isolated $E$. paraensei (PCerc-1) cercariae from Glyptophysa sp. snails in Townsville, Australia by molecular analysis [41]. In New Zealand, a species closely allied to E. revolutum was found by molecular studies [41], and 2 more species, E. novaezealandense and E. mizagawai, were discovered [24]. Thus, at least 5 species are existing in Oceania, including E. revolutum, E. acuticauda, E. miyagawai, E. novaezealandense, and E. paraensei (Table 3).

\section{SPECIES OF 37-COLLAR-SPINED ECHINOSTOMA GROUP}

\section{Echinostoma revolutum (Froelich, 1802) Dietz, 1909}

[syn. Echinostoma armatum Barker \& Irvine, 1915; Echinostoma audyi Lie \& Umathevy, 1965; Echinostoma columbae Zunker, 1925; Echinostoma dilatatum (Miram, 1940) Cobbold, 1860; Echinostoma echinocephalum (Rudolphi, 1819) Cobbold, 1860; Echinostoma erraticum Lutz, 1924; Echinostoma ivaniosi Mahandas, 1973; Echinostoma limicoli Johnson, 1920; Echinostoma mendax Dietz, 1909; Echinostoma microrchis Lutz, 1924; Echinostoma neglectum Lutz, 1924; Echinostoma nephrocystis Lutz, 1924; Echinostoma oxycephalum (Rudolphi, 1819) Railliet, 1896; Echinostoma revolutum tenuicollis Bashikirova, 1941; Echinostoma revolutum var. japonicum Kurisu, 1932; Echinostoma stromi Bashikirova, 1946; Echinostoma sudanense Odhner, 1910]

This species (Fig. 3) was originally described under the name Fasciola revoluta based on adult flukes found in the large intestine of wild ducks Anas boschas fereae dissected on July 20, 1798 in Germany [4]. It was about $11 \mathrm{~mm}$ long and had 37 collar spines, and these morphological features have served as the main basis for further definitions of E. revolutum [4]. A year later, E. echinatum (under the name Distoma echinatum) was described by Zeder in Germany, and this name (D. echinatum or E. echinatum) had been used for about a hundred years until Dietz $[16,17]$ renamed $F$. revoluta as Echinostoma revolutum in his systematic reorganization of the Echinostomatidae and synonymized E. echinatum with E. revolutum. Dietz $[16,17]$ also synonymized Echinostoma dilatatum (under the name Distoma dilatatum Miram, 1940) and Echinostoma armatum (under the name Distoma armatum Molin, 1858) with E. revolutum. This was a big milestone for the taxonomy of E. revolutum and 37-collar-spined Echinostoma group. After Dietz [16,17], adult worms and larval stages found in Europe, Asia, Africa, Australia, and North and South America have been described as E. revolutum for at least 70-80 years $[1,4,19,20,32,88,94-98]$ (Table 4). On the other hand, Kanev [20] and Kanev et al. [33] suggested the taxonomic validity of E. echinatum, and Schuster [99], Christensen et al. [100], and Huffman and Fried [7] supported it (see E. echinatum section). However, the validity of $E$. echinatum was recently put to a question by Kostadinova and Gibson [26], Georgieva et al. [10], and Faltýnková et al. [11].

Human infection with $E$. revolutum was first described in Taiwan in 1929 [101]. Later, in 1982, the prevalence of E. revolutum among Taiwan population was reported to be $0.11-0.65 \%$ [102]. Further human infections were reported in mainland China [12], Indonesia [103], Thailand [104], Cambodia [51], and Lao PDR [56]. However, all of these reports are not based on molecular confirmation and need further verification regarding the species identification.

Kanev [4] studied on almost all previous records on E. revolutum and other 37-collar-spined group and delimited the definition of $E$. revolutum. He stated that 37-collar-spined echinostomes cannot be morphologically identified only by adult flukes but they can be more clearly discriminated by the morphology of larval stages, in particular, the cercariae, and hostparasite relationships. Thus, E. revolutum was delimited as those flukes having (1) lymnaeid snails as the 1st intermediate host, (2) various pulmonate and prosobranch snails, mussels, frogs, and freshwater turtles as the second intermediate host, (3) only birds as the definitive host, (4) cercariae and adults armed with 37 collar spines, (5) geographical distribution 

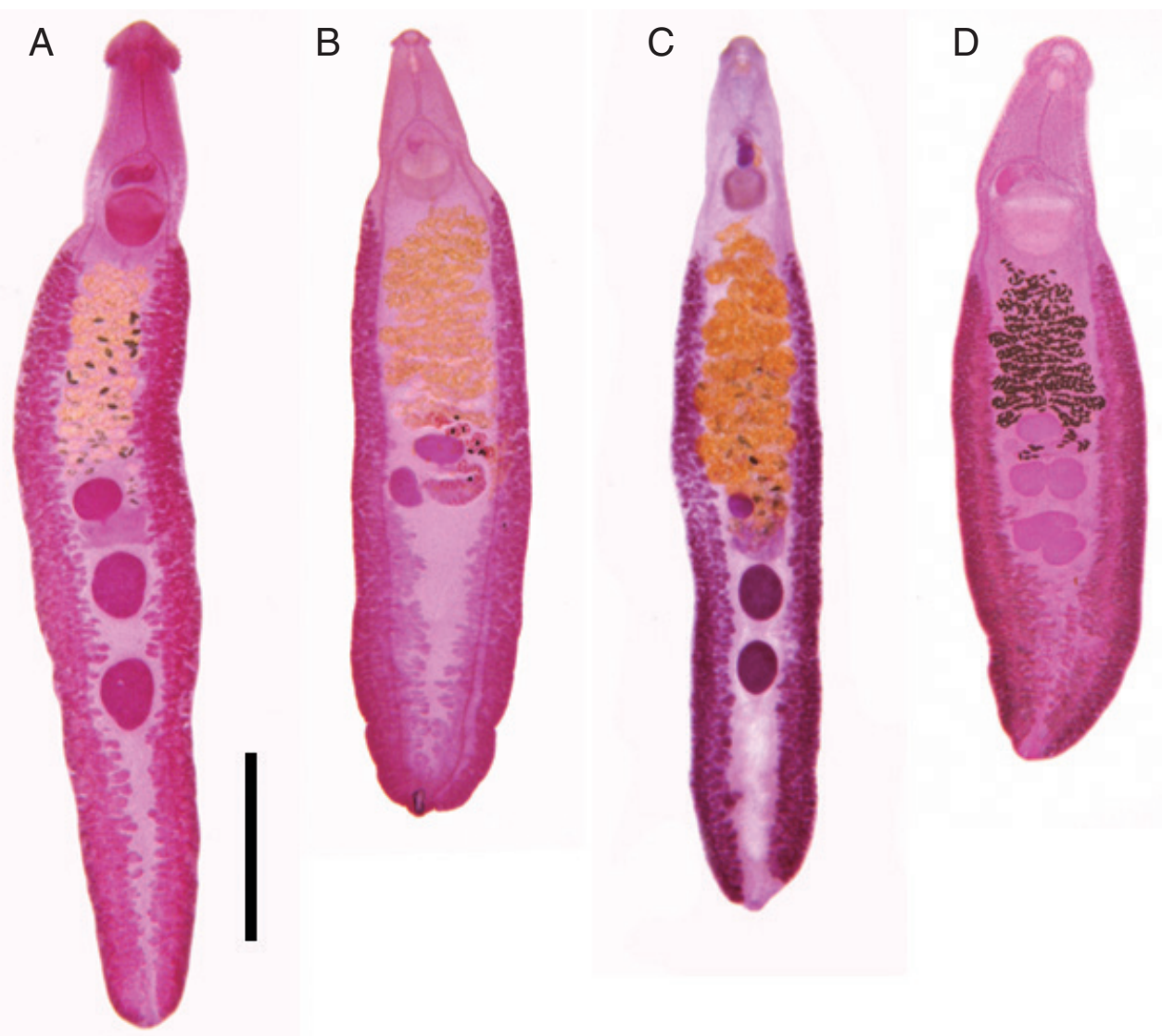

Fig. 3. Adult specimens of Echinostoma revolutum (A) from Thailand (courtesy of Prof. Chalobol Wongsawad, Chiang Mai University), E. cinetorchis (B) from South Korea, E. mekongi (C) from Cambodia, and E. robustum (D) from India under the same magnification. Scale bar $=2 \mathrm{~mm}$.

only in Europe and Asia, (6) Cercaria echinata Siebold, 1937, E. echinatum, and E. jurini as closely related species in Europe, and (7) specific characteristics only in larvae and host-parasite relationships [4]. However, some of these delimitations had to be revised because of various new findings. Using molecular data, Detwiler et al. [31] confirmed that both lymnaeid and planorbid snails can serve as the 1st intermediate host of $E$. revolutum. Detwiler et al. [42] also confirmed that E. revolutum can infect a mammalian host, the muskrat Ondatra zibethicus, in USA. The geographical distribution of E. revolutum was extended to North and South America, and Oceania [31,41,42,91] (Tables 3, 4). Faltýnková et al. [11] redescribed the morphology of rediae, cercariae, and adults of E. revolutum based on European samples (from Germany, Finland, Czech Republic, Poland, Bulgaria, and Iceland). In comparison with the report of Kanev [4], they found in the cercariae 6 outlets of penetration gland-cells (4 outlets in Kanev [4]) and total 12 outlets of paraesophageal gland-cells (16-20 outlets in Kanev [4]) [11] (Ta- ble 5).

Molecular analysis of E. revolutum was started by Morgan and Blair [35]. They compared the nucleotide sequences of ITS region (ITS1-5.8S-ITS2) of E. revolutum (originated from Germany) with those of E. trivolvis, E. paraensei, E. caproni (including E. liei and Echinostoma sp. II from Africa), and Echinostoma sp. I from Africa (E. deserticum). They concluded that E. revolutum was phylogenetically close to E. trivolvis and E. paraensei but distinct from one another, and far from E. caproni and $E$. deserticum. Morgan and Blair [41,105] further compared the usefulness of ITS region and 2 mitochondrial loci ( $\operatorname{cox} 1$ and nad1) to discriminate the species and found that nad1 appeared to be the most informative locus for investigating phylogenetic relationships within the 37-collar-spined Echinostoma group. The molecularly distinct status of E. revolutum in relation to other species and other genera has been supported by Kostadinova et al. [40].

The existence of E. revolutum in North America (under the 
Table 4. Geographical distribution of 26 valid or validity-retained 37-collar-spined Echinostoma species

\begin{tabular}{|c|c|}
\hline Species and nominator & $\begin{array}{c}\text { Continent and country where this species } \\
\text { has been reported }\end{array}$ \\
\hline E. revolutum ${ }^{\mathrm{a}}$ & $\begin{array}{l}\text { Asia, Europe, North America, South } \\
\text { America, Oceania }\end{array}$ \\
\hline E. acuticauda & Australia \\
\hline E. barbosai & Brazil \\
\hline E. bolschewense & Czech Republic, Russia, Slovak Republic \\
\hline E. caproni & $\begin{array}{l}\text { Cameroon, Congo, Egypt, Madagascar, } \\
\text { Togo }\end{array}$ \\
\hline E. chloephagae & Argentina \\
\hline E. cinetorchis & $\begin{array}{l}\text { China, Indonesia, Japan, South Korea, } \\
\text { Taiwan, Vietnam }\end{array}$ \\
\hline E. deserticum & Algeria, Niger \\
\hline E. echinatum & Europe (Germany and other countries) \\
\hline E. jurini & $\begin{array}{l}\text { Europe (Bulgaria, Russia, and other } \\
\text { countries) }\end{array}$ \\
\hline E. lindoense & $\begin{array}{l}\text { Indonesia, Malaysia, The Philippines, } \\
\text { Thailand }\end{array}$ \\
\hline E. luisreyi & Brazil \\
\hline E. mekongi & Cambodia \\
\hline E. miyagawai & Asia, Europe, Oceania \\
\hline E. nasincovae & Czech Republic, Slovak Republic \\
\hline E. novaezealandense & New Zealand \\
\hline E. nudicaudatum & UK \\
\hline E. paraensei & Australia, Brazil \\
\hline E. paraulum & $\begin{array}{l}\text { Austria, Bangladesh, China, Czech } \\
\text { Republic, Germany, Pakistan, Russia }\end{array}$ \\
\hline E. parvocirrus & Guadeloupe (West Indies) \\
\hline E. pinnicaudatum & UK \\
\hline E. ralli & Japan \\
\hline E. robustum ${ }^{c}$ & Asia, Europe, North America, South America \\
\hline E. rodriguesi & Argentina, Brazil \\
\hline E. trivolvis & North America (Canada, USA) \\
\hline $\begin{array}{l}\text { Echinostoma sp. IG } \\
\text { Georgieva et al., } 2013\end{array}$ & Germany, Iceland, UK \\
\hline
\end{tabular}

This table has been updated from Chai (2019) [3].

${ }^{a}$ Asia (Bangladesh, China, India, Indonesia, Iran, Japan, Lao PDR, Malaysia, South Korea, Taiwan, Thailand, and Vietnam), Europe (Austria, Belarus, Bulgaria, Czech Republic, Finland, France, Germany, Greece, Hungary, Iceland, The Netherlands, Poland, Russia, Slovak Republic, UK, Yugoslavia), North America (USA), South America (Brazil), Oceania (New Zealand).

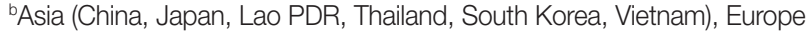
(Austria, Bulgaria, Czech Republic, Hungary, Poland, Russia, Spain, Ukraine), Oceania (New Zealand).

'Asia (Bangladesh, China, Japan, Taiwan), Europe (Germany, Poland, Russia, UK, Uzbekistan), North America (USA), South America (Brazil).

name E. echinatum, actually E. trivolvis) was first documented in 1888 [106] followed by others in 1895 [107] and 1896 [108]. In the first document, the specimen was found in muskrats from Pennsylvania [19,42], and the next documents were about findings from rabbits and chickens, respectively $[107,108]$. In 1937, Beaver [19] reported E. revolutum from experimentally infected birds and mammals, and Fried and coworkers performed extensive works thereafter (more than 70 studies during 1968-1988) under the name E. revolutum [7]. However, Kanev $[4,20]$ mentioned that E. revolutum of Beaver [19] and all other North American literature dealing with E. revolutum until 1988 were supposed to have been E. trivolvis.

The true existence of $E$. revolutum in North America was first confirmed by Sorensen et al. [86] who found naturally infected freshwater snails Lymnaea elodes shedding 37-collar-spined cercariae in Indiana, USA. They experimentally infected various snail species to obtain the metacercariae, which were given to chicken and geese to obtain the adult flukes. Sorensen et al. [87] notified intraspecific variation in ITS loci sequences among isolates of E. revolutum (North American and European) and also E. trivolvis (different localities in Indiana). The existence of $E$. revolutum in North America was again confirmed by Detwiler et al. [31,42] through molecular analysis of ITS region, cox1, and nad1 loci. In addition, Detwiler et al. [31] reported that both lymnaeid and planorbid snails can serve as the first intermediate host of E. revolutum and E. trivolvis in USA. Detwiler et al. [42] also confirmed that E. revolutum can infect a mammalian host, the muskrat in USA. Phylogenetic trees based on mitochondrial cox1 (Fig. 1) and nad1 (Fig. 2) sequences of 7 and 14 Echinostoma species, respectively, show their phylogenetic relationships.

The nad 1 sequence variation among the "E. revolutum group" indicated that $E$. revolutum haplotypes from Europe formed a monophyletic group which clustered closely with a monophyletic group of isolates from North America [45]. In Asia, molecular genetic studies were conducted on E. revolutum in comparison with Hypoderaeum conoideum, Echinoparyphium recurvatum, and Artyfechinostomum malayanum (under the name Echinostoma malayanum) using multilocus enzyme electrophoresis and sequencing of ITS1 and cox1 $[52,53,109,110]$. However, isolates from Southeast Asia were not included in the study of Georgieva et al. [45] due to the lack of nad1 data [72]. Subsequently, it was found that E. revolutum from Southeast Asia (Thailand and Lao PDR) clustered as a monophyletic clade with the European isolates, named as "Eurasian lineage", and this was distinct from the American isolates, which was named as "American lineage" [72]. This nad1-based genetic variation of $E$. revolutum according to geographical locations has been supported by an analysis of cytochrome B (CYTB) gene [75]. Mohanta et al. [46] accepted the 2 genetic lineages of $E$. revolutum using ITS2 and nad 1 sequences. However, Buddhachat 
Table 5. Characteristics of Echinostoma revolutum in comparison with closely related species ${ }^{a}$

\begin{tabular}{|c|c|c|c|c|c|}
\hline & E. revolutum & E. lindoense & E. miyagawai & E. robustum & E. trivolvis \\
\hline Definitive host & birds, mammals & mammals & birds, mammals & birds & birds, mammals \\
\hline 1st intermediate host & $\begin{array}{l}\text { lymnaeid and planorbid } \\
\text { snails }\end{array}$ & $\begin{array}{l}\text { lymnaeid and planorbid } \\
\text { snails }\end{array}$ & $\begin{array}{l}\text { lymnaeid and planorbid } \\
\text { snails }\end{array}$ & lymnaeid snails & $\begin{array}{l}\text { lymnaeid and planorbid } \\
\text { snails }\end{array}$ \\
\hline $\begin{array}{l}\text { No. of outlets of } \\
\text { penetration gland-cells } \\
\text { (cercaria) }\end{array}$ & 6 & 6 & 6 & $?$ & 6 \\
\hline $\begin{array}{l}\text { No. of outlets of } \\
\text { paraesophageal } \\
\text { gland-cells (cercaria) }\end{array}$ & 12 & $60-64$ & $42-46$ & $?$ & $4-6$ \\
\hline $\begin{array}{l}\text { Size of metacercariae } \\
(\mu \mathrm{m})\end{array}$ & 132-152 (diameter) & $120-130$ (in diameter) & 144-154 (in diameter) & $?$ & $135-170$ (in diameter) \\
\hline Collar spines (adult) & $\begin{array}{l}\text { slender and sharply } \\
\text { pointed }\end{array}$ & $\begin{array}{l}\text { short and less sharply } \\
\text { pointed }\end{array}$ & $\begin{array}{l}\text { small with sharply } \\
\text { pointed ends }\end{array}$ & $\begin{array}{l}\text { innermost end group } \\
\text { spines smaller than } \\
\text { others }\end{array}$ & very sharply pointed \\
\hline $\begin{array}{l}\text { Body constriction near } \\
\text { the ventral sucker level } \\
\text { (adult) }\end{array}$ & no constriction & $\begin{array}{l}\text { constricted at middle } \\
\text { level of ventral } \\
\text { sucker }\end{array}$ & $\begin{array}{l}\text { constricted at posterior } \\
\text { end level of ventral } \\
\text { sucker }\end{array}$ & $\begin{array}{l}\text { constricted at posterior } \\
\text { end level of ventral } \\
\text { sucker }\end{array}$ & no constriction \\
\hline Shape of testes (adult) & $\begin{array}{l}\text { smooth or slightly } \\
\text { lobed }\end{array}$ & deeply lobed & $\begin{array}{l}\text { subglobular and } \\
\text { indented, } 3 \text { lobed }\end{array}$ & $\begin{array}{l}\text { irregularly lobed and } \\
\text { horizontally extended }\end{array}$ & $\begin{array}{l}\text { smooth, oval orslightly } \\
\text { irregular }\end{array}$ \\
\hline $\begin{array}{l}\text { Vitellaria confluence near } \\
\text { the posterior end of } \\
\text { body (adult) }\end{array}$ & not confluent & confluent & confluent & confluent & confluent \\
\hline
\end{tabular}

${ }^{a}$ Other closely related species include E. cinetorchis (reduced number and abnormal location of testes), E. mekongi (remarkably variable in body shape and morphology of testes, i.e., globular, slightly or deeply lobed; smaller head collar, collar spines, oral and ventral suckers, and cirrus sac compared to E. revolutum and E. miyagawai; vitellaria not confluent), E. paraensei (dorsalmost collar spines smaller than others), and E. paraulum (slight median indentation in 2 testes).

and Chontananarth [111] used DNA barcoding of cox 1 and nad 1 in combination with high-resolution melting analysis to identify E. revolutum and found that the E. revolutum clade of nad 1 phylogeny obtained from the Thai isolate formed a different lineage from the Eurasian lineage. Thus, the nad 1 phylogenetic tree revealed 3 lineages of E. revolutum; Asian, Eurasian, and American lineages [111]. The complete mitochondrial genome (17,030 bp) of E. revolutum was obtained and characterized by Le et al. [112] in comparison with 9 echinostome species, including E. caproni, E. mizagawai, and E. paraensei. They concluded that $E$. revolutum grouped in a monophyletic subclade as a sister taxon to E. miragawai and paraphyletic to other echinostomatids in the Echinostomatidae [112]. A multiplex PCR technique targeting the nad 1 gene has been developed for differential detection of 4 medically important echinostome species, including E. revolutum [113].

After E. miyagawai was first described from domestic fowls and domestic and wild ducks in 1932 in Japan [114], Beaver [19] raised synonymy of E. mizagawai with E. revolutum. Yamaguti $[1,97]$ accepted this synonymy but Russian researchers, including Bashikirova [96] and Skrjabin and Bashikirova [32], denied the synonymy. Kosupko $[115,116]$ was the first who ap- plied complex morphological and ecological approaches to distinguish E. revolutum and E. miyagawai and validated the 2 species as separate taxa on the basis of their morphological differences in cercariae and adults, ontogenic development, first intermediate and final host preferences, and their distribution in the host intestine. Nevertheless, Kanev [4] denied the validity of E. miyagawai and synonymized it with E. echinatum. Kostadinova et al. [21] re-validated E. miyagawai to be distinct from E. revolutum and E. echinatum of Kanev $[1,20]$ on the basis of experimental completion of its life cycle. According to them, the adult worms of E. miragawai were characterized by having a very elongate body with a constriction at the posterior border of the ventral sucker (no constriction in E. revolutum), a large head collar with relatively small collar spines (larger collar spines in E. revolutum), a spherical ventral sucker which is only about half the maximum body width (larger ventral sucker in E. revolutum), a long cirrus-sac reaching posteriorly to the middle of the ventral sucker (to the anterior border of ventral sucker in E. revolutum), indented subglobular testes (globular or slightly lobed in E. revolutum), and vitellaria forming 2 lateral fields of follicles which are almost confluent in the posttesticular space (not confluent in E. revolutum) [21] (Table 5). 
In addition, they [36] suggested 5 morphometric variables to distinguish E. miyagawai from E. revolutum, which included body width at posterior border of the ventral sucker, head collar width, length of the esophagus, width of the ventral sucker, and length of the pre-ovarian region.

\section{Echinostoma acuticauda Nicoll, 1914}

This species was originally described from a bird (strawnecked ibis Carphibis spinicollis) in North Queensland, Australia [93]. It was put to a synonymy with E. revolutum as a synonym inquirenda by Beaver [19]; however, this synonymy has not been followed by succeeding authors, for example, Mendheim [95], Jones and Anderson [23], Georgieva et al. [24], and Memon et al. [67]. This species is morphologically close to $E$. novaezealandense described from New Zealand but has a shorter forebody, more anteriorly located ovary and testes, and much larger eggs [24]. However, the taxonomic status of $E$. acuticauda should be re-evaluated by detailed morphological as well as molecular studies in the near future.

\section{Echinostoma barbosai Lie \& Basch, 1966}

E. barbosai was originally described from pigeons, chicks, and ducklings experimentally infected with the metacercariae from Biomphalaria glabrata snails in Brazil [117]. This species resembled E. audyi (a synonym of $E$. revolutum) but was smaller in size of adults and different in cercarial characteristics and the first intermediate host [117]. E. barbosai was also found in Bulgaria by Kanev group [118]. However, Mutafova and Kanev [119] synonymized this species with E. echinatum, because the karyotype of E. barbosai was completely corresponded to that of E. echinatum. This synonymy was agreed by Huffman and Fried [7] and Fried and Graczyk [8]. However, Kostadinova and Gibson [26] doubted the status of both species, E. echinatum and E. barbosai. Meanwhile, Latin American authors continue to use the name E. barbosai $[27,30,120,121]$. Under this situation, the name E. barbosai should be retained until further confirmatory studies with molecular data are provided.

\section{Echinostoma bolschewense (Kotova, 1939) Nasincova, 1991}

This species originates from Cercaria bolschewensis Kotova, 1939 shed from prosobranch snails in the European part of Russia [122]. Later, the adult fluke, named as E. bolschewense, was collected from the small intestine of experimentally infected hamsters through a life cycle study in South Bohemia,
Czech Republic [122]. Kanev [4] and Kanev et al. [5] regarded this species a synonym of E. jurini. However, Georgieva et al. [10] studied on nad 1 and $28 \mathrm{~S}$ rDNA sequences of E. bolschewense in the cercarial stage from Slovak Republic and found that E. bolschewense is genetically distinct from E. revolutum, E. trivolvis, E. caproni, E. paraulum, and E. mizagawai (but molecular data of $E$. jurini are yet unavailable). In addition, Faltýnková et al. [11] analyzed the differential morphological features of larval and adult stages of $E$. bolschewense in comparison with those of E. juri reported by Kanev et al. [5] and acknowledged the validity of E. bolschewense. However, they did not place $E$. jurini in synonymy with $E$. bolschewense. To re-validate the 2 closely related species, E. bolschewense and E. jurini, comparative molecular studies are required.

\section{Echinostoma caproni Richard, 1964}

[syn. Echinostoma liei Jeyarasasingam et al., 1972; Echinostoma togoensis Jourdan \& Kulo, 1981]

This echinostome was originally reported from the small intestine of naturally infected birds (kestrels; Falco newtoni) and a domestic fowl experimentally infected with the metacercariae in a freshwater snail Bulinus liratus in Madagascar [80]. The cercariae (under the name E. liei) were also found in Biomphalaria alexandrina snails collected in Egypt which were experimentally infected to B. glabrata and other snail species to obtain the metacercariae and then to chicks and hamsters to obtain the adult flukes [83]. This echinostome was also reported in Togo (under the name E. togoensis) which developed into rediae in Biomphalaria pfeifferi, metacercariae in aquatic pulmonate snails, and adults in laboratory mice [84]. The synonymy of E. liei and E. togoensis with E. caproni was proposed by Huffman and Fried [7] and Fried and Huffman [85] which was followed by other workers $[3,26]$. In addition, Kanev [20], Huffman and Fried [7], and Christensen et al. [100] synonymized E. paraensei with E. caproni. However, Sloss et al. [34] and Morgan and Blair [35] suggested that E. paraensei is distinct from E. caproni based on different isoenzyme electrophoretic patterns and DNA sequences of ITS region. E. caproni was studied also under the name of $E$. revolutum by many workers, including Barus et al. [123], Christensen [124], Christensen et al. [125-128], Bindseil and Christensen [129], and Simonsen and Andersen [130] as mentioned by Fried and Huffman [85].

The molecular data (cox1 and nad1) of E. caproni have been available by Morgan and Blair [35,41,105] and Macilla [72]. E. caproni was phylogenetically close to E. trivolvis as shown by 
cox1 sequences [72]. Cytochrome B gene was also found to be useful to differentiate African E. caproni from South American E. paraensei and Asian E. revolutum [75].

\section{Echinostoma chloephagae Sutton \& Lunaschi, 1980}

E. chloephagae was first discovered from the rectum of a bird Chloephaga picta melanoptera in Argentina [131]. This species continued to be recorded from naturally infected birds, including C. picta leucoptera, in Argentina [29]. Metacercariae of seemingly E. chloephagae were detected in a bivalve species $\mathrm{Di}$ plodon chilensis in Argentina, and adult flukes were obtained from experimentally infected chickens with the metacercariae [30]. The taxonomic validity of this species in comparison with other 37-collar-spined Echinostoma spp. should be evaluated in the near future, through morphological as well as molecular studies.

\section{Echinostoma cinetorchis Ando \& Ozaki, 1923}

This echinostome (Fig. 3) was originally described based on specimens recovered from the small intestine of wild rats in Japan by Ando and Ozaki [59], and redescribed by Dollfus [132] in French. Kurisu [69] and Sugimoto [133] found this echinostome in the intestine of domestic fowls in Japan and a dog in Taiwan, respectively. Tanabe and Takeishi [134] reported a low prevalence $(1.65 \%)$ of E. cinetorchis in rats Rattus norvegicus captured around Tokyo, Japan. In South Korea, this echinostome was reported from wild rats [135,136] and dogs [137]. Its life cycle was successfully completed in the laboratory using Hippeutis cantori snails as the source for cercariae and metacercariae [61]. Human infection with E. cinetorchis was first reported in Japan [138-140], and then in Korea [60,141144]. Now, it is well known as a zoonotic echinostome infecting humans, rodents, and poultries in Asian countries, including Japan, South Korea, China, Taiwan, Indonesia, and Vietnam [3,92,145-148].

Beaver [19] synonymized E. cinetorchis with E. revolutum based on their morphologic similarities, including the number of collar spines $(\mathrm{n}=37)$ and dimensions of internal organs and eggs. However, this synonymy was not justified by other workers due to various reasons, including, in particular, the unique feature of $E$. cinetorchis having testes that move to abnormal locations and even disappear from the body during the worms grow up to be adults (Table 5) as well as differences in selecting the snail host $[1,3]$. This species is thought to reproduce parthenogenetically without testes and sperms. Now
E. cinetorchis is acknowledged as a distinct species $[2,3,92,149]$. In 2016, nad1 sequences of E. cinetorchis were deposited based on materials (adult flukes) obtained from South Korea by Lee et al. (to be published) in GenBank; the sequences are unique and clearly separated from those of E. revolutum Eurasian and American lineages.

\section{Echinostoma deserticum Kechemir, Jourdane \& Mas- Coma, 2002}

E. deserticum was described as a new species from the small intestine of the African grass rat Arvicanthis niloticus from Niger [43]. The majority of adult flukes do not have testes; some have only 1 testis and very rarely 2 testes [43] which is highly similar to E. cinetorchis. This species is thought to reproduce parthenogenetically without testes and sperms [43]. Sporocysts and rediae were isolated from Bulinus truncatus and B. globosus snails from south of Algeria and Niger [43].

Molecular studies on this species were done under the name of Echinostoma sp. I from Niger by Morgan and Blair $[35,41,105]$ in 1995 before it was formally described as a new species in 2002. The sequences of ITS region and mitochondrial cox 1 and nad 1 loci indicated that $E$. deserticum is the most distinct in comparison with other 37-collar-spined echinostomes, including E. revolutum, E. trivolvis, E. paraensei, and E. caproni (also E. liei and Echinostoma sp. II) $[35,41,87,105]$. In addition, the nad 1 sequence of $E$. deserticum appears to be markedly different from that of the morphologically similar species, E. cinetorchis, deposited in GanBank, with sequence homology of only $84.7 \%$.

\section{Echinostoma echinatum (Zeder, 1803) de Blainville, 1828}

[syn. Echinostoma londonensis Khan, 1961]

E. echinatum was described in 1803 under the name Distoma echinatum from birds and mammals (?) in Germany, with detailed descriptions of collar spines $[4,150]$. A year before (1802), Fasciola revoluta (=E. revolutum) was described by Froelich from birds in Germany [4]. In 1809, Rudolphi erected a subgeneric group Echinis (Echinostoma) within the genus Disto$m a$ and placed F. revoluta as the type species [4]. After Rudolphi, however, F. revoluta was out of use, and its function as the type species was replaced by Distoma echinatum Zeder, 1803 [4]. Practically almost all 37-collar-spined echinostomes found in Europe from Rudolphi in 1809 until Dietz in 1909 were diagnosed as D. echinatum [4]. However, Dietz [16,17] restored the validity of $F$. revoluta renaming it as $E$. revolutum in his systemat- 
ic reorganization of the echinostomatid flukes and synonymized D. echinatum with E. revolutum. A list of adult and larval worms described under the name D. echinatum was transferred to E. revolutum by Dietz [4]. Thereafter, over 500 articles dealing with this echinostome have described the species name as $E$. revolutum [4]. Beaver [19], Mendheim [95], Bashikirova [96], Skrjabin and Bashikirova [32], and Yamaguti [1,97] followed this synonymy, and the name E. echinatum disappeared for some time.

Later, however, E. echinatum was revived by Kanev $[4,20]$ and Kanev et al. [5,33] based on various differential characters from E. revolutum and E. jurini; for example, E. echinatum took both lymnaeid and planorbid snails as the first intermediate host, whereas E. revolutum and E. jurini took only lymnaeid and viviparid snails, respectively. The definitive host of E. echinatum was birds and mammals, including humans, whereas $E$. revolutum infected only avian hosts, and E. jurini infected only mammalian animals [5]. The 3 species also differed in the cercarial chaetotaxy and developmental period of eggs and cercariae [5,33]. The validity of E. echinatum was supported by other workers, including Schuster [99], Christensen et al. [100], Huffman and Fried [7], and Fried and Graczyk [8].

However, some of the differential characters suggested above were denied by succeeding authors; for example, it turned out that $E$. revolutum can infect mammalian hosts too, i.e., muskrats in USA, based on molecular analysis of nad 1 sequences [42]. In addition, E. revolutum can take both lymnaeid and planorbid snails as the first intermediate host in USA [31,42]. Moreover, Kostadinova [151] criticized Kanev and coworkers' report of E. echinatum (sensu Kanev $[4,20]$ and Kanev et al. [33]) stating that re-examination of the voucher specimens identified by Kanev et al. [33] as E. echinatum showed 2 other distinct species; Echinostoma sarcinum Dietz, 1909 possessing 47 collar spines and Echinostoma sp. (E. echinatum?) with 37 collar spines.

Regarding E. lindoense, its geographical distribution was reported to extend from the original Asian countries (Indonesia and Malaysia) to Brazil [152], Poland, Czechoslovakia (now Czech Republic and Slovak Republic) [153], and Spain [154]. Based on this, Kanev [4] described that E. echinatum is distributed in different geographical regions of Asia, South America, and Europe, including Germany, where E. echinatum was originally described. However, Kostadinova and Gibson [26] doubted the synonymy of $E$. lindoense with $E$. echinatum because of the remarkable differences in the cercarial morpholo- gy. Moreover, the validity of E. echinatum remains to be re-validated because E. echinatum has not been formally described in a taxonomic publication $[10,11,45]$. In GenBank, molecular data under the name E. echinatum is so far unavailable and should be provided in order to re-validate its taxonomic status. Because of the unique cercarial and adult worm morphology (see E. lindoense section), the name E. lindoense should be retained until molecular data in comparison with E. echinatum (currently unavailable) become available.

\section{Echinostoma jurini (Skvortsov, 1924) Kanev, 1985}

[syn. Echinostoma orlovi Romashov, 1966; Echinostoma sisjakowi (Skvortsov, 1935) Yamaguti, 1971]

E. jurini was originally described under the name Cercaria jurini based on cercariae shed from viviparid snails collected along the Volga River in Russia [5]. Nasinkova [122] stated that the description of C. jurini Skvortsov, 1924 was so inaccurate and incomplete that it cannot be considered a description of a species. Later, this species was redescribed by Kanev [20] and Kanev et al. [5] based on larvae and adults obtained experimentally starting from naturally infected Viviparus contectus and V. viviparus snails collected along the Danube River in Bulgaria. The metacercariae were obtained from the renopericardial sac of laboratory-raised snails, Physa acuta and P. fontinalis after exposure to the cercariae, and adults were recovered from experimental hamsters, rats, and mice [5]. The morphology of adult flukes closely resembled that of E. revolutum; however, Kanev [4] and Kanev et al. [5] validated this species because of differences in selecting intermediate and definitive hosts and differences in the morphology of cercariae. They stated that $E$. jurini infects viviparid snails and mammals, whereas E. revolutum infects lymnaeid snails and avian hosts. They put a variety of echinostome species in possible synonymy with E. jurini, which included E. orlovi Romashov, 1966, Echinostoma sisjakowi (Skvortsov, 1934) Yamaguti, 1971, and Echinoparyphium sisjakowi (Skvortsov, 1934).

The validity of $E$. jurini was acknowledged by Kostadinova and Gibson [26], Fried and Graczyk [8], and Toledo et al. [9]. However, Kostadinova and Gibson [26] criticized that the conclusions made by Kanev et al. [5] that "Practically, all 37-collarspined adults of Echinostoma spp. in mammals in Europe (including E. bolschewense) might be identical with E. jurini." appeared to be an overestimate of the degree of morphological variability in the absence of an experimental support. Moreover, Georgieva et al. [10] obtained nad1 and 28S rDNA se- 
quences of $E$. bolschewense adults originating from Viviparus acerosus snails in the river Danube, Slovak Republic and found that $E$. bolschewense is genetically distinct from E. revolutum, $E$. trivolvis, E. caproni, E. paraulum, and E. miyagawai. However, molecular data of E. jurini have not yet been reported [72]. Faltýnková et al. [11] analyzed differential morphological features of larval and adult stages of $E$. bolschewense in comparison with those of E. juri reported by Kanev et al. [5]. The cercariae of E. jurini had 6 outlets for the penetration gland-cells and 8-10 outlets for the paraesophageal gland-cells on the dorsal lip of the oral sucker [5]; however, the cercariae of $E$. bolschewense possessed 10 outlets for the penetration glandcells ( 6 median and 4 medio-lateral) and lacks paraesophageal gland-cells [11]. Furthermore, the adults of E. bolschewense had much larger eggs (138-162 ×75-85 $\mu \mathrm{m})$ than those of $E$. jurini (96-132 $\times 72-88 \mu \mathrm{m})$ [11]. Based on these characters, they denied the synonymy raised by Kanev et al. [5] giving remarks on the validity of $E$. bolschewense. They neither placed $E$. jurini in synonymy with E. bolschewense. To re-validate these 2 closely related species comparative molecular studies seem to be urgently needed.

\section{Echinostoma lindoense Sandground \& Bonne, 1940}

This species was first described from human patients in the Lake Lindoe region of Central Celebes, Indonesia [63]. This echinostome was also discovered from humans in Jakarta, Indonesia and then animals, including rats in Malaysia, Thailand, and the Philippines [155-157]. An echinostome species similar in their morphology and biology to $E$. lindoense was also found in Brazil [152] and European countries, including Bulgaria, Poland, Czech Republic, Slovak Republic, Germany, Austria, UK, and Russia $[153,158]$. However, the E. lindoense reported from Europe and South America needs reconfirmation through molecular analysis with Asian (Indonesian) species.

The major differential points of E. lindoense from E. revolutum included morphology of larval stages (particularly the cercariae) and adults; in cercariae E. lindoense had 2 dorsal, 2 ventral, and 2 small ventrolateral tail fin-folds, whereas E. revolutum had only 1 small dorsal fin-fold near the tip of the tail [158]. In addition, the testes of E. lindoense in adults were deeply indented (Asian strain) or superficially lobed (Brazilian strain; this needs re-evaluation), but those of E. revolutum are smooth or only slightly lobated [4,152] (Table 5). E. lindoense has shorter and wider collar spines than $E$. revolutum which has longer and slender collar spines with more or less pointed ends [103].

The larval and adult stages of $E$. lindoense were morphologically and biologically similar to those of E. echinatum originating from Germany, and thus E. lindoense was synonymized with E. echinatum by Kanev and coworkers $[4-6,20,33]$. This synonymy was accepted by Huffman and Fried [7], Fried and Graczyk [8], Toledo et al. [149], and Toledo and Esteban [148]. However, Kostadinova and Gibson [26] and Kostadinova et al. $[21,36]$ questioned about the taxonomic validity of E. echinatum, because of its many uncertain points, for example, a wide range (more than 20) of the number of paraesophageal glandcell outlets in cercariae, and E. echinatum has not been properly reported as a taxonomic publication. The questionable status of E. echinatum was agreed in subsequent publications, including Georgieva et al. [10,45] and Fáltynková et al. [11]. Unfortunately, E. lindoense has not yet been molecularly analyzed. Chai [3] tentatively acknowledged the validity of $E$. lindoense.

\section{Echinostoma luisreyi Maldonado, Vieira \& Lanfredi, 2003}

E. luisreyi Maldonado et al., 2003 was originally described from mice and hamsters experimentally infected with metacercariae from Physa marmorata and B. glabrata snails in Brazil [44]. The most important morphological character of this species was the oral corner spines that increase in size from the latero-oral to the ventro-oral regions [44]. Later, a rodent species, Akodon montensis, was found to be a natural definitive host [159]. Fried and Graczyk [8], Toledo et al. [9], and Georgieva et al. [10] recognized this species to be distinct among the 37-collar-spined E. revolutum group, and Pinto and Melo [27] mentioned about the cercariae of this species that emerged from P. marmorata snails in Brazil. This echinostome might have been zoonotic 600-1,200 years ago in Brazil, since eggs morphologically suggestive of $E$. huisreyi were found from the coprolites of human mummies [160]. Another report suggesting E. luisreyi or E. paraensei infection in a mummified body (520-600 years before present) of a human in Brazil mentioned that the eggs in coprolites were morphologically similar to E. huisreyi but molecularly (cox1 gene; $83 \mathrm{bp}$ ) closer to E. paraensei [15]. Molecular data of E. luisreyi are not yet available in GenBank.

\section{Echinostoma mekongi Cho, Jung, Chang, Sohn, Sinuon \& Chai, 2020 \\ E. mekongi (Fig. 3) was reported based on adult flukes recov- ered from human infections after praziquantel treatment and}


purging in Kratie and Takeo Province, Cambodia along the Mekong River, which is molecularly distinct from E. revolutum and 13 other 37-collar-spined Echinostoma spp. deposited in GenBank [49]. Adults of this species were 9.0-13.1 in length and 1.3-2.5 $\mathrm{mm}$ in maximum width and the eggs in feces and worm uterus were 98-132 $\mu \mathrm{m}$ long and 62-90 $\mu \mathrm{m}$ wide [49]. The adult worms closely resembled those of E. revolutum, E. miyagawai, and several other 37-collar-spined Echinostoma species [49]. However, this species revealed remarkable variation in body shape and morphology of the testes (globular, slightly or deeply lobed), and smaller head collar, collar spines, oral and ventral suckers, and cirrus sac compared to E. revolutum and E. mizagawai [49] (Table 5). Sequencing of 2 mitochondrial genes (nad1 and cox1) and a nuclear ITS region (ITS1-5.8S rRNA-ITS2) revealed unique features distinct from E. revolutum (Southeast Asian, Eurasian, European, and American lineages) and other 37-collar-spined Echinostoma group available in GenBank (E. bolschewense, E. caproni, E. cinetorchis, E. miyagawai, E. nasincovae, E. novaezealandense, E. paraensei, E. paraulum, E. robustum, E. trivolvis, and Echinostoma sp. IG) [49]. Studies on biological and epidemiological characteristics, including the life cycle, geographical distribution, and source of human infections, are urgently needed [49].

\section{Echinostoma miyagawai Ishii, 1932}

[syn. Echinostoma friedi Toledo, Muñoz-Antolí \& Esteben, 2000]

This species was first described from domestic fowls, domestic ducks, and wild ducks in Japan [114]. Later, an experimental human infection was found successful in China [12]. Beaver [19] synonymized E. miyagawai with E. revolutum because of their morphological similarities, including the size and arrangement of collar spines, morphology of 2 testes, and size of the oral and ventral suckers, pharynx, and other internal organs. Yamaguti $[1,97]$ accepted this synonymy. However, Russian researchers, including Bashikirova [96] and Skrjabin and Bashikirova [32], denied this synonymy. In particular, Kosupko [115-116] applied complex morphological and ecological approaches to distinguish E. revolutum and E. miyagawai and validated the 2 species on the basis of their morphological differences in the cercariae and adults, ontogenic development, first intermediate and final host preferences, and their distribution in the host intestine. Opposed to this, Cooper [161] and Kanev [4] denied the validity of E. miyagawai and synonymized it with E. revolutum or E. echinatum, respectively. Later, however,
Kostadinova [162] and Kostadinova et al. [21,36] re-validated E. miyagawai on the basis of unique cercarial chaetotaxy and morphometric data of E. mizagawai in comparison with E. revolutum through experimental completion of its life cycle. The adult worms of E. miyagawai were characterized by a considerably elongate body with a constriction at the posterior border of the ventral sucker, a large head collar with relatively small collar spines, a spherical ventral sucker which is only about half the maximum body width, a long cirrus-sac reaching posteriorly to the middle of the ventral sucker, indented subglobular testes, and vitellaria forming 2 lateral fields of follicles which are almost confluent in the post-testicular space [21] (Table 5). In addition, Kostadinova et al. [36] suggested 5 morphometric variables to distinguish E. miyagawai from $E$. revolutum, which included body width at the posterior border of ventral sucker, head collar width, length of esophagus, width of ventral sucker, and length of the pre-ovarian region. Fried and Graczyk [8] and Toledo et al. [9] acknowledged the taxonomic validity of this species. E. friedi reported as a new species by Toledo et al. [39] in 2000 was synonymized with $E$. miyagawai based on morphological data by Faltýnková et al. [11].

Molecular data (nad1 and $28 \mathrm{~S}$ rRNA) of E. miyagawai have been available since Georgieva et al. [10]. The nad1 analysis showed that E. miyagawai is in a distinct clade clearly separated from E. revolutum (sensu stricto; European), E. revolutum (American lineages), E. paraulum, and E. caproni [10]. This E. miyagawai clade incorporates $E$. friedi reported in GenBank by Marcilla et al. (AJ564379, Valencia, Spain) [10] and E. revolutum German strain (AF065832) by Morgan and Blair $[41,105]$. Nagataki et al. [72] found that E. miyagawai from Southeast Asia was monophyletic with European isolates, named as "Eurasian lineage", which was slightly different from "Australian lineage" with no significant genetic differentiation being observed between these lineages. Fu et al. [73] and Li et al. [74] obtained the complete mitochondrial genome of E. miyagawai (Hunan isolate or Heilongjiang isolate, China) which was 14,416 or 14,468 bp in size and consisted of 12 protein-coding genes, 22 transfer RNA genes, 2 ribosomal RNA genes, and 1 non-coding region. Mohanta et al. [46] suggested a synonymy of E. robustum, E. miyagawai, and E. friedi based on nad 1 sequence analysis. However, Heneberg [47] did not agree to this synonymy but suggested that G1-G11 isolates from Bangladesh designated as E. robustum were in fact $E$. miyagawai. The taxonomic validities of both E. miyagawai and E. robustum have 
been acknowledged by various workers $[21,31,36,42]$.

The geographical distribution of E. miyagawai has been extended from Japan [163] to South Korea [64,65], Russia [164], China [12,73,74], Vietnam [165], Thailand, Lao PDR [72], Bulgaria [21,36,162], Austria and Hungary [166], Poland [167], Spain (under the name of E. friedi) [39], Czech Republic [11], and New Zealand [24] (Table 4).

\section{Echinostoma nasincovae Faltýnková, Georgieva, Soldánová \& Kostadinova, 2015}

[syn. Echinostoma spiniferum (La Valette, 1855) sensu Nasincova, 1992; Echinostoma revolutum of Nasincova, 1986]

Našincová [168] described the life cycle of an echinostome species she believed to be E. revolutum in Central Europe, which she had completed in the laboratory based on cercariae from Planorbarius corneus snails [11]. Later, she recognized that the cercariae described from $P$. corneus differs from the cercariae of $E$. revolutum in the pattern of paraesophageal gland-cells and used the name Echinostoma spiniferum in her Ph.D. thesis in 1992 [11]. Later, Georgieva et al. [10] described a new species of Echinostoma (named as Echinostoma n. sp.) based on molecular dataset of nad 1 and $28 \mathrm{~S}$ rDNA sequences during the analyses of 37-collar-spined Echinostoma spp. in Europe. This Echinostoma n. sp. formed a unique genetic clade neighbored with E. paraensei and 3 lineages (A-C) of E. trivolvis $[31,42]$ and remotely joined by 3 isolates of E. caproni [10]. Faltýnková et al. [11] described this as a new species, E. nasincovae, synonymizing E. revolutum of Našincová [168] and $E$. spiniferum (La Valette, 1855) sensu Našincová, 1992 with E. nasincovae. They [11] described that its snail intermediate host is $P$. corneus, the definitive host is experimental hamsters, and the geographical localities included Czech Republic and Slovak Republic. In 2008, Faltýnková et al. [166] found Gyraulus albus, P. corneus, Planorbis planorbis, and Bathyomphalus contortus from Czech Republic, Slovak Republic, Germany, and Poland acting as the snail hosts for E. spiniferum (synonym of E. nasincovae). Schwelm et al. [169] also listed G. albus as a snail host for E. nasincovae.

The cercariae of E. nasincovae differed from the cercariae of other species of Echinostoma within the 'revolutum' group in small body size, 6 ducts of penetration gland-cells opening on the dorsal lip of the oral sucker, and 30-39 outlets of paraesophageal gland-cells, of which 8 are located in the region of the oral sucker and 22-31 are confined to the area between esophagus and the dilated portion of the main collecting ex- cretory ducts [11]. The adult of E. nasincovae was most similar to $E$. revolutum and E. bolschewense. However, compared with $E$. revolutum, E. nasincovae had smaller body and organs, smaller angle, lateral, and dorsal collar spines, and smaller eggs [11]. Compared with E. bolschewense, E. nasincovae had smaller body length and width, smaller egg length, smaller lateral and dorsal spine length, and smaller ovary and testes [11].

\section{Echinostoma novaezealandense Georgieva, Blasco- Costa \& Kostadinova, 2017}

In 1998, Morgan and Blair [41] discovered an unidentified 37-collar-spined Echinostoma sp. adults (NZ-Ad) from the gut of a wild Canada goose (Branta canadensis) in New Zealand. This isolate (AF026289) was molecularly distinct from E. revolutum and $E$. paraensei based on the sequence of nad 1 gene [41]. Later, the same flukes were recovered from the small intestine and rectum of 2 avian species, a wild duck (Anas platyrhynchos) and a black swan (Cygnus atratus), in Central Otago District, New Zealand, and morphological and molecular studies (nad 1 and $28 \mathrm{~S}$ rDNA) were performed [24]. The nad 1 sequences of 2 isolates from the ducks (KY436398 and KY436399) and 1 isolate from the swan (KY436397) revealed strong association with that of NZ-Ad (AF026289) of Morgan and Blair showing a unique position in the phylogenetic tree neighboring with $E$. miyagawai, E. paraulum, and E. robustum/friedi lineages [24]. The $28 \mathrm{~S}$ rDNA sequence of 1 isolate from the swan (KY436407) also revealed a unique position neighboring with E. miyagawai, E. paraulum, E. revolutum, Echinostoma sp. IG, E. trivolvis, E. paraensei, and E. nasincovae [24]. Thus, the adult specimens were described as a new species, E. novaezealandense [24]. This species was morphologically close to E. acuticauda described in Australia but differed in having a longer forebody, more posteriorly located ovary and testes, and much smaller eggs [24]. This species is now listed among the helminth fauna of birds in New Zealand [170].

\section{Echinostoma nudicaudatum Nasir, 1960}

This species was first described from the intestine of experimental pigeons infected with the metacercariae from L. stagnalis snails in Birmingham, UK [171]. The species name came from the fact that the cercariae had no fin-folds on the tail [171]. The cercariae of E. revolutum have a fin-fold on the tail, rod-like cystogenous gland-cells, and 36 (possibly more) flame cells, but those of E. nudicaudatum were in the complete lack of a fin-fold on the tail, granular gland-cells in the cercarial 
body, and at least 94 flame cells [171]. The adults of E. nudicaudatum differed from those of E. revolutum, E. robustum, and E. lindoense in the absolute sizes of collar spines, and from $E$. ralli in the arrangement of collar spines [171]. Interestingly, intra-redial encystment of the cercariae (i.e., metacercariae) was observed within the rediae of $E$. nudicaudatum, which means precocious encystment in snails $[172,173]$, as observed similarly in E. trivolvis [6].

During the experimental life cycle, production of at least 3 redial generations was observed [172]. A year after the discovery of $E$. nudicaudatum, E. pinnicaudatum (the name came from the cercariae having a well-developed dorso-ventral fin-fold) was reported as a new species, from the same place where $E$. nudicaudatum was discovered [174]. In adult flukes, only a minor difference was found in the arrangement of collar spines between E. nudicaudatum and E. pinnicaudatum; in the former there were 7 unalternating lateral spines but in the latter there were 5 unalternating collar spines [174]. The cercariae of these 2 species were recorded among the cercarial fauna from British freshwater molluscs [175]. However, taxonomic attention has seldom been paid to these 2 species of Echinostoma spp., and further studies to evaluate their taxonomic validity through molecular analysis are needed.

\section{Echinostoma paraensei Lie \& Basch, 1967}

This species was originally described from Brazil based on experimentally obtained adults from mammalian hosts, including hamsters, mice, and rats infected with the metacercariae from B. glabrata snails [176]. Later, this fluke was detected from naturally infected water rats, Nectomys squamipes, in Brazil $[89,90]$. It is of note that the eggs of E. paraensei (less probably E. hisreyi) were detected in the coprolite of a mummified human body in Brazil using molecular techniques [15].

The adult $E$. paraensei resembled adults of $E$. revolutum, $E$. lindoense, and E. barbosai; however, the minute size of 5-11 dorsalmost collar spines was characteristic for E. paraensei [176] (Table 5). Kanev [20] considered E. paraensei a synonym of $E$. caproni based mainly on the fact that $E$. paraense $i$ also uses species of Biomphalaria as the 1st intermediate host. Huffman and Fried [7] accepted this concept, and Kanev [4] listed only 5 species in the 37-collar-spined group, which included E. revolutum (sensu stricto), E. trivolvis, E. caproni, E. jurini, and E. echinatum excluding E. paraensei. However, E. paraensei was acknowledged as a distinct species because of its unique isoenzymatic patterns [34], DNA sequences [35], patterns of random amplification of polymorphic DNA (RAPD) [177], host-parasite relationships [178], and unique metacercarial excystation patterns and morphological features [179]. The validity of $E$. paraensei was agreed by Fried and Huffman [85], Kostadinova and Gibson [26], Fried and Graczyk [8], and Toledo et al. [9].

Molecular data of $E$. paraensei have been available since Morgan and Blair $[35,41,105]$ who analyzed the ITS region, cox1, and nad 1 of E. paraensei (from Australia) and other 37-collarspined Echinostoma spp. The results evidenced that $E$. paraensei (PCer-1) is distinct from E. caproni and phylogenetically rather close to E. trivolvis [35,41,105]. In addition, Morgan and Blair [41] found an isolate (cercariae from Glyptophysa sp. snails; AF026282) of E. paraensei from Townsville, Australia, which diverged from the Brazilian species (AF025834) by only 2 nucleotide substitution out of 530 sequenced. Georgieva et al. [10] further reported that $E$. paraensei was grouped with $E$. nasincovae (under the name Echinostoma n. sp.) and E. trivolvis forming a second clade among the 37-collar-spined Echinostoma group. Recently, cytochrome B gene was found to be useful to differentiate E. paraensei from Asian E. revolutum and African E. caproni [75].

\section{Echinostoma paraulum Dietz, 1909}

This species was originally described from the bird Colymbus cristatus and several species of ducks from Central Europe, including Austria and Russia $[4,16,17,19]$. Miller [180] described this species in North America (Canada) and synonymized Echinostoma columbae Zunker, 1925 with E. paraulum. However, Kanev et al. [6] regarded Miller's specimens as E. trivolvis, whereas Beaver [19] synonymized E. columbae with E. revolutum. Human infection with E. paraulum was reported from Russia in 1938 [181] and also from Yunnan Province, China in 1979 [14]. The rediae and cercariae were found in P. corneus, and the metacercariae were found in Planorbis carinatus snails [182]. This host selection was different in E. revolutum; rediae and cercariae developed in Lymnaea palustris and metacercariae in $P$. corneus [182]. The metacercariae of E. revolutum were bigger having a thick cyst wall but those of $E$. paraulum were smaller having a thin cyst wall [182].

Skrjabin [183], Sprehn [184], Skrjabin and Bashikirova [32], and Iskova [185] supported the taxonomic validity of E. paraulum; however, Beaver [19], Yamaguti [1,97], and Kanev [4,20] denied the validity and synonymized it with $E$. revolutum. Beaver [19] mentioned that 37 collar spines of E. paraulum were arranged exactly as in E. revolutum, its relative size of various 
organs was identical with that of E. revolutum, and there was not a single character by which $E$. paraulum can be separated from $E$. revolutum. Yamaguti $[1,97]$ synonymized various species with E. revolutum, including E. echinatum, E. armatum, E. revolutum var. japonicum, E. mivagawai, and E. paraulum. Kanev $[4,20]$ confirmed its complete life cycle from Europe, including Austria where E. paraulum was originally described and concluded that $E$. paraulum corresponded completely with $E$. revolutum. Thereafter, Huffman and Fried [7], Kostadinova and Gibson [26], Fried and Graczyk [8], and Toledo et al. [9] did not recognize $E$. paraulum as a distinct species.

Georgieva et al. [10] was the first who molecularly confirmed the unique status of E. paraulum. They obtained 5 isolates from cercariae $(4 ;$ L. stagnalis $)$ and an adult $(1 ;$ Aythya fuligula) originating from Germany and Czech Republic, respectively, and analyzed nad 1 and 28S rDNA sequences together with other 37-collar-spined Echinostoma spp. The phylogenetic tree of nad 1 showed that $E$. paraulum was distinct from all other species analyzed and included within the 1st clade where $E$. revolutum (sensu lato), E. miyagawai, E. novaezealandense (as Echinostoma sp. NZ-Ad), and E. robustum/friedi are located [10]. The phylogenetic tree of $28 \mathrm{~S}$ rDNA supported this showing similar findings [10]. They also mentioned that although $E$. paraulum and E. revolutum use the same snail species (L. stagnalis) as their 1st intermediate host, the cercariae of $E$. paraulum were dissimilar to those of $E$. revolutum in the pattern of paraesophageal gland-cells [10]. Subsequently, the morphology and life cycle of E. paraulum were redescribed by Faltýnková et al. [11]. According to them, the cercariae of E. paraulum were much larger in size with a much longer tail than those of $E$. revolutum, possessing a larger number of paraesophageal glandcell outlets than the cercariae of $E$. revolutum. The adults of $E$. paraulum were in comparison with the same age of E. revolutum much smaller in size, with a more robust body, longer forebody, and distinctly wider head collar, and notably their testes had a characteristic median constriction [11] (Table 5). Nagataki et al. [72] supported the validity of E. paraulum using nad1 analysis of 37-collar-spined Echinostoma spp. and mentioned that E. paraulum formed a sister group with E. robustum and E. miragawai. Mohanta et al. [46] also established a phylogenetic tree based on nad 1 which supported the taxonomic validity of $E$. paraulum. Adult E. paraulum was reported from the house crow in Pakistan [67] and ducks in Bangladesh [66]. However, the specimen from Pakistan showed testes with no distinct median constriction, and thus the specific diagnosis needs reconfirmation.

\section{Echinostoma parvocirrus Nassi \& Dupouy, 1988}

This species was described as a new species from the naturally infected B. glabrata snails in Guadeloupe, French West Indies [38]. This snail host served as both the 1st and 2nd intermediate host (metacercariae also in P. marmorata snails and tadpoles of Bufo marinus), and birds (ducklings of Cairina moschata and canaries) served as the experimental definitive host [38]. The adults morphologically resembled E. trivolvis (under the name E. multispinosum reported from birds in Cuba), E. revolutum (under the name E. mendax reported from birds in Brazil), and E. barbosai (from birds in Brazil) but differed in body length, size of oral and ventral suckers, pharynx, and other organs [38]. In the cercariae of E. parvocirrus, the number of penetration gland-cell pores was 6 ( 4 in E. barbosai), and the number of paraesophageal gland-cell pores at the cephalic portion was 8 ventral and 4 dorsal (11 ventral and 6 dorsal in E. barbosai) [38]. This species has been listed among the 37-collar spined 'E. revolutum' spp. by Kostadinova and Gibson [26], Fried and Graczyk [8], Maldonado and Lanfredi [92], Toledo et al. [9], Nagataki et al. [72], and Le et al. [112]. However, taxonomic attention on this species has been scarce, and there has been no information on molecular characteristics.

\section{Echinostoma pinnicaudatum Nasir, 1961}

This species was described based on adult flukes obtained from a laboratory-raised pigeon experimentally fed the metacercariae in L. stagnalis snails from Birmingham, UK [174]. The snails had both cercarial and metacercarial stages, and collected in the same locality where E. nudicaudatum was discovered $[171,174]$. The adults of E. pinnicaudatum were morphologically close to $E$. nudicaudatum with only a recognizable difference in the arrangement of collar spines; in the former there were 5 unalternating lateral spines, whereas in the latter there were 7 of these [174]. However, the morphology of cercariae was distinctly different. In the cercaria of E. pinnicaudatum there was a well-developed, dorso-ventral fin-fold (as the name 'pinnicaudatum' indicates) but in the cercaria of E. nudicaudatum the finfold was totally absent [174]. The cercariae of E. pinnicaudatum was recorded among the cercarial fauna from British freshwater molluscs [175]. However, taxonomic attention has never been paid to E. pinnicuadatum, and further studies to evaluate its taxonomic validity through molecular analysis should be performed. 


\section{Echinostoma ralli Yamaguti, 1934}

This species was originally described from the small intestine of a waterfowl, Rallus aquaticus indicus in Aichi, Shiga, and Shizuoka Prefecture, Japan [68]. Later, this species was found again in the same species of birds in Fukuoka Prefecture, Japan [186] and in the bird Fulica atra in Azerbaidzhan [1]. The adult worms had total 37 collar spines with 4 end group spines on each side, cup-shaped ventral sucker, and vitellaria beginning at the level of the posterior end of the ventral sucker [68]. It resembled E. revolutum (including synonyms E. mendax, E. erraticum, E. microrchis, and E. neglectum), E. paraulum, and E. acuticauda but differed in the number of end group spines, size of eggs, and others [68]. No further information is available on this species, and its taxonomic validity should be re-evaluated providing molecular data.

\section{Echinostoma robustum Yamaguti, 1935}

E. robustum (Fig. 3) was first described from the small intestine of 2 naturally infected avian species, Streptopelia chinensis formosa and Columba livia domestica, in Taiwan [187]. Domestic pigeons, chickens, and ducks, wild ducks, and wild geese were also found to be definitive hosts $[1,97]$. This species is morphologically close to E. miyagawai (and E. friedi) but can be differentiated in several features, including the morphology of testes, irregularly and deeply lobed and horizontally extended in E. robustum whereas subglobular with irregular margins or 3 lobed in E. miyagawai $[46,98,187]$ (Table 5). In addition, the size of the ventral sucker in comparison to the body width is smaller in E. miyagawai [21] than in E. robustum [187]. The existence of this species has been extended to Japan [18], China [188], Bangladesh [46,66,70], Russia [78,79], Uzbekistan, Azerbaidzhan, Georgia, Estonia, Bulgaria [1], Poland [77], UK [76], USA [31,42], and Brazil [31] (Table 4). Cercariae develop in freshwater snails (Radix lagotis, R. auricularia, and Planorbis sp.), and encyst in the same or different snails (Radix spp. or Cristaria plicata), fish (Hemiculter leucisculus, Acheilognathus chankaensis, or Gobio gobio), or frogs (Rana temporaria) [79].

This species was synonymized with $E$. revolutum by Bezubik in 1956, but soon acknowledged as a distinct species by Rayski and Fahmy [76] in 1962 and listed in Skrjabin and Bashikirova [32] and Yamaguti [1,97]. However, Huffman and Fried [7], Kanev [4], Kostadinova and Gibson [26], Fried and Graczyk [8], and Toledo et al. [9] did not recognize this as a valid species. Kanev [4] synonymized this species with E. echinatum; however, it appeared to be inappropriate since E. echinatum it- self needs revalidation $[10,11,45]$. The validity of $E$. robustum was supported by Detwiler et al. [31,42] through molecular analyses (cox1, nad1, and ITS) of isolates from Indiana and Minnesota, USA and Minas Gerais, Brazil. Georgieva et al. [45] indicated that $E$. friedi sensu Marcilla et al. (unpublished, in GenBank only, AJ564379) and E. revolutum of Morgan and Blair [35,41,105] (AF025832) from Europe had strong association with E. robustum sensu Detwiler et al. [31] from USA (GQ463053, GQ463054) and Brazil (GQ463055). The clade comprising of these 5 isolates exhibited a complex structure suggesting the existence of at least 3 different species [45]. Further studies are needed to back up this suggestion.

In addition, the clones of E. robustum sensu Detwiler et al. [31] and E. friedi (Marcilla et al., unpublished) showed almost identical nad 1 sequences and formed together subclades 'a-d' (E. robustum/E. friedi lineage). However, E. friedi was synonymized with E. miyagawai based on morphological analyses [11]. Mohanta et al. [46] suggested a synonymy between E. robustum, E. miyagawai, and E. friedi based on analysis of nad 1 sequences; however, Heneberg [47] did not agree to this synonymy but suggested that the G1-G11 isolates designated as $E$. robustum by Mohanta et al. [46] were in fact E. mivagawai. In this respect, whether E. miyagawai and E. robustum are taxonomically distinct species, despite several morphological differences [46], needs additional studies. Moreover, whether the specimens from Indiana and Minnesota (USA) and Brazil [31] are conspecific with the original E. robustum from Taiwan requires reconfirmation.

\section{Echinostoma rodriguesi Hsu, Lie \& Basch, 1968}

Adults of this species were originally reported from experimental chicks, pigeons, hamsters, and mice fed the metacercariae in laboratory-raised B. glabrata snails in California, USA; the cercariae were originally obtained from Physa rivalis snails in Minas Gerais, Brazil and the infected snails were shipped to California [37]. P. rivalis also served as the 2nd intermediate host [37]. In adults of E. rodriguesi, the arrangement of collar spines resembled those of E. revolutum, E. lindoense, E. barbosai, and $E$. paraensei, and the size and shape of collar spines and testes were indistinguishable from those of $E$. audyi (synonym of E. revolutum) and E. barbosai [37]. However, the number of flame cells on the cercariae was 21 pairs in E. rodriguesi, E. lindoense, and E. paraensei but E. barbosai had 24 pairs, and E. revolutum (under the name E. audyi) had 27 pairs [37]. This species was also reported from rodents in Argentina $[189,190]$. 
Regarding its taxonomic validity, Kanev [20] was of opinion that $E$. rodriguesi may be a synonym of E. trivolvis, and Kostadinova and Gibson [26] did not list this species as a distinct species. Fried and Graczyk [8] and Toledo et al. [9] also excluded E. rodriguesi from the list of 37-collar-spined Echinostoma group. However, Kanev et al. [6] suggested that E. trivolvis occurred only in North America and did not include E. rodriguesi among the synonyms of $E$. trivolvis. In addition, Kanev et al. [18] used the name E. rodriguesi and mentioned about the migration of sporocysts within the snail body as a characteristic feature. Thereafter, E. rodriguesi has been acknowledged as a distinct species and mentioned by various researchers, including Latin American workers [27,44,89,90,120,189-191]. However, molecular data have not been provided for E. rodriguesi, and thus further validation of this species is needed.

\section{Echinostoma trivolvis (Cort, 1914) Kanev, 1985}

[syn. Echinostoma armigerum Barker and Irvine, 1915; Echinostoma callawayensis Barker and Noll, 1915; Echinostoma coalitum Barker and Beaver, 1915; Echinoparyphium contiguum Barker and Bastron, 1915; Echinostoma multispinosum Pérez Vigueras, 1944]

This species originated from Cercaria trivolvis, its rediae, and metacercariae in the North American planorbid snail, Helisoma trivolvis (under the name Planorbis trivolvis) from Urbana, Illinois, USA $[192,193]$. The adult flukes of this species were described earlier in North America under the name E. echinatum by Leidy from musk rats in 1888 [106] followed by Stiles and Hassall from cotton rabbits in 1895 [107] and Hassall from chickens in 1896 [108]. They were also described under different names E. armigerum and E. coalitum by Barker on the specimens from muskrats in Nebraska in 1915 [194] and from muskrats in Ontario, Canada by Law and Kennedy in $1932[19,195]$.

Beaver [19] studied on C. trivolvis shed from Helisoma trivolvis snails, obtained adult flukes in the laboratory, and assigned them as E. revolutum. Later, however, Kanev [20] and Kanev et al. [6] pointed out that the E. revolutum of Beaver [19] was actually E. trivolvis, and many of the articles published from North America until 1988 under the name E. revolutum should be reconsidered as having been E. trivolvis. Later, the true existence of E. revolutum in North America was morphologically as well as molecularly confirmed by Sorensen et al. [86,87]; it was transmitted by L. elodes snails in Indiana, USA. In addition, based on nad1 gene sequences, the American E. revolutum was shown to be genetically different from European popula- tions [10,31].

The morphological details of E. trivolvis larvae and adults were described by Kanev et al. [6]. He used the C. trivolvis shed from H. trivolvis snails collected from Douglas Lake, Michigan, USA as the starting point and obtained metacercariae from the pericardial sac of laboratory-raised P. acuta and P. fontinalis snails and adults from golden hamsters, rats, mice, ducks, geese, chickens, pigeons, turkeys, partridges, and guinea fowls. The first intermediate host also included Physa gyrina snails at St. Joseph, Illinois, USA [196]. Metacercariae developed also in the pericardial sac and posterior kidney region of mussels ( $A n$ odonta cygnea) and various freshwater snails, including Viviparus viviparus, V. contectus, $L$. stagnalis, $L$. tomentosa, $L$. truncatula, $L$. palustris, L. peregra, L. auricularia, P. corneus, B. glabrata, B. alexandriana, Bithynia tentaculata and B. leachi, and kidney and eye socket of tadpoles and frogs and freshwater turtles [6]. Precocious encystment of metacercariae within rediae was observed [6]. C. trivolvis has 37 collar spines, 7 fin-folds on the tail, 2 pairs of 3 flame cells at the level of the pharynx and total 36 flame cells, 6 pores of penetration gland-cells along the esophagus, and 4-6 pores of paraesophageal gland-cells on the oral sucker [6]. The cercariae were also described under different names, C. trisolenata Faust, 1917, C. acanthostoma Faust, 1918, and C. complexa Faust, 1919 [6]. The metacercariae were 135$170 \mu \mathrm{m}$ in diameter, having a thick outer cyst wall and a thin inner cyst wall [6]. The adult flukes had a variable body size, from 3-5 mm to 20-30 mm, variable body shape, from elongate, flattened dorso-ventrally, and tapering posteriorly, to broad, with a tapering anterior end and a bluntly rounded posterior end [6].

E. trivolvis is different from E. revolutum in various points, including the number and arrangement of protein fractions in adult worm homogenates, number and distribution of argentophilic structures [197], number and position of paraesophageal gland-cell ducts in cercariae (4-6 on the oral sucker only in the former and 12 on the oral sucker and body in the latter), and geographical distribution $[4,6,11]$ (Table 5). Sloss et al. [34] showed different electrophoretic patterns between $E$. trivolvis, E. caproni, and E. paraensei.

Kanev et al. [6] synonymized E. armigerum, E. callawayensis, E. coalitum, E. multispinosum, and Echinoparyphium contiguum with E. trivolvis. Kanev [20] also considered E. rodriguesi a synonym of E. trivolvis but later Kanev et al. [6] denied the presence of $E$. trivolvis in South America and did not list $E$. rodriguesi among the synonyms of E. trivolvis. The distinct taxonomic 
status of E. trivolvis has been acknowledged by Huffman and Fried [7], Kostadinova and Gibson [26], Fried and Graczyk [8], Maldonado and Lanfredi [92], Toledo et al. [9], Detwiler et al. [31,42], and Georgieva et al. [10,24,45].

The molecular data of $E$. trivolvis have been available after Morgan and Blair [35] who compared the nucleotide sequences of ITS region (ITS1-5.8S-ITS2) with those of E. revolutum, E. paraensei, E. caproni (including E. liei and Echinostoma sp. II), and Echinostoma sp. I (E. deserticum). They concluded that $E$. trivolvis was phylogenetically close to E. revolutum and E. paraensei but distinct from one another and far from E. caproni and Echinostoma sp. I (E. deserticum). Sorensen et al. [87] notified intraspecific variation in ITS loci among isolates of $E$. trivolvis (different localities in Indiana) and E. revolutum (North American and European). The nad1 and cox 1 sequences became available after Morgan and Blair [41] and Detwiler et al. $[31,42]$. The clones used were 3 from the cercariae of E. trivolvis from $H$. trivolvis and $L$. elodes snails in Indiana and Minnesota and 1 from the adult worm recovered in muskrats in Wiscon$\sin [31]$. The nad 1 phylogeny demonstrated that the muskrats were infected with 5 echinostome lineages; 3 E. trivolvis lineages, 1 E. revolutum, and 1 Echinoparyphium lineage 1 [31]. High levels of intraspecific variation with 3 lineages of $E$. trivolvis suggested the existence of multiple cryptic species within $E$. trivolvis [31,42].

\section{Echinostoma sp. IG of Georgieva, Selbach, Faltýnková, Soldánová, Sures, Skírnisson \& Kostadinova, 2013}

[syn. Echinostoma cf. friedi of Kostadinova et al. (2003)]

Echinostoma sp. IG is a tentative name of a unique species but not yet formally described [45]. It was based on a larval stage (cercariae) from Radix peregra in Iceland and R. auricularia in Germany [11,45]. Its molecular information has been available for nad 1 and $28 \mathrm{~S}$ rDNA sequences $[10,45]$. Cercariae and rediae ex. Planorbis sp. snails found in Wales, UK showing unique molecular characteristics [40] were also assigned to this species [11]. The cercariae of this species were unique having distal dorsal fin-fold and 12 paraesophageal gland-cell outlets restricted to the region of the oral sucker [11]. The adult stage has not yet been found [11].

\section{CONCLUSION}

A total of 26 Echinostoma species are recognized as valid (16 species) or validity-retained (10) among the 37-collar-spined
Echinostoma spp. around the world. The morphology of the cercarial stage as well as the size and shape of adult flukes, including the relative size of the oral and ventral suckers, size, shape, and arrangement of collar spines, and morphology of testes and cirrus sac as well as arrangement of vitelline follicles are important criteria for species differentiation. However, some of these species are difficult to distinguish one from the other only by morphology. Molecular techniques, in particular, gene sequencing of mitochondrial $\operatorname{cox} 1$ and nad1, is a highly useful technique for discriminating the species and seems to be essential to determine the taxonomic validity of 37-collar-spined Echinostoma spp. group.

\section{ACKNOWLEDGMENT}

We are grateful to the staff of Institute of Parasitic Diseases, Korea Association of Health Promotion, Seoul, Korea who helped echinostome studies.

\section{CONFLICT OF INTEREST}

We have no conflict of interest related to this study.

\section{REFERENCES}

1. Yamaguti S. Synopsis of digenetic trematodes of vertebrates. Vol. I. Tokyo, Japan. Keigaku Publishing Co. 1971, pp 1-1074.

2. Chai JY. Echinostomes in humans. In Fried B, Toledo R, eds, The Biology of Echinostomes. New York, USA. Springer. 2009, pp 147-183.

3. Chai JY. Human Intestinal Flukes. Chapter 2. Echinostomes. The Netherlands. Springer Nature B.V. 2019, pp 169-343.

4. Kanev I. Life-cycle, delimitation and redescription of Echinostoma revolutum (Froelich, 1802) (Trematoda: Echinostomatidae). Syst Parasitol 1994; 28: 125-144.

5. Kanev I, Dimitrov V, Radev V, Fried B. Redescription of Echinostoma jurini (Skvortzov, 1924) with a discussion of its identity and characteristics. Ann Naturhist Mus Wien 1995; 97B: 37-53.

6. Kanev I, Fried B, Dimitrov V, Radev V. Redescription of Echinostoma trivolvis (Cort, 1914) (Trematoda: Echinostomatidae) with a discussion on its identity. Syst Parasitol 1995; 32: 61-70.

7. Huffman JE, Fried B. Echinostoma and echinostomiasis. Adv Parasitol 1990; 29: 215-269.

8. Fried B, Graczyk TK. Recent advances in the biology of Echinostoma species in the 'revolutum' group. Adv Parasitol 2004; 58: 139-195.

9. Toledo R, Esteban JG, Fried B. Recent advances in the biology 
of echinostomes. Adv Parasitol 2009; 69: 147-204.

10. Georgieva S, Faltýnková A, Brown R, Blasco-Costa I, Soldánová M, Sitko J, Scholz S, Kostadinova A. Echinostoma 'revolutum' (Digenea: Echinostomatidae) species complex revisited: species delimitation based on novel molecular and morphological data gathered in Europe. Parasit Vectors 2014; 7: 520.

11. Faltýnková A, Georgieva S, Soldánová M, Kostadinova A. A reassessment of species diversity within the 'revolutum' group of Echinostoma Rudolphi, 1809 (Digenea: Echinostomatidae) in Europe. Syst Parasitol 2015; 90: 1-25.

12. Mao SP. Protozoan and helminth parasites of humans in mainland China. Int J Parasitol 1991; 21:347-351.

13. Chai JY. Chapter 19. Echinostomes. In Xiao L, Ryan U, Feng Y eds, Biology of Foodborne Parasites. Boca Raton, USA. CRC Press, Taylor \& Francis Group. 2015, pp 427-443.

14. Li T, He S, Zhao H, Zhao G, Zhu XQ. Major trends in human parasitic diseases in China. Trends Parasitol 2010; 26: 264-270.

15. Leles D, Cascardo P, Freire A dos S, Maldonado Jr A, Sianto L, Araujo A. Insights about echinostomiasis by paleomolecular diagnosis. Parasitol Int 2014; 63: 646-649.

16. Dietz E. Die Echinostomiden der Vögel. Zool Anz 1909; 34 : 180-192 (in German).

17. Dietz E. Die Echinostomiden der Vögel. Zool Jarb 1910; Suppl XII: 265-512 (in German).

18. Kanev I, Sterner M, Radev V, Fried B. An overview of the biology of echinostomes. In Fried B, Graczyk TK eds, Echinostomes as Experimental Models for Biological Research. Dordrecht, Boston, London. Kluwer Academic Publishers, Amsterdam, The Netherlands. 2000, pp 1-29.

19. Beaver PC. Experimental studies on Echinostoma revolutum (Froelich), a fluke from birds and mammals. Illin Biol Monogr 1937; 15: 1-96.

20. Kanev I. On the morphology, biology, ecology and taxonomy of E. revolutum group (Trematoda: Echinostomatidae: Echinostoma). Ph.D. Thesis. University of Sofia, Bulgaria. 1985.

21. Kostadinova A, Gibson DI, Biserkow V, Chipev N. Re-validation of Echinostoma miyagawai Ishii, 1932 (Digenea: Echinostomatidae) on the basis of the experimental completion of its life-cycle. Syst Parasitol 2000; 45: 81-108.

22. Chai JY. Intestinal flukes. In Murrell KD, Fried B eds, FoodBorne Parasitic Zoonoses. Fish and Plant-Borne Parasites. New York, USA. Springer. 2007, pp 53-115.

23. Jones A, Anderson TJC. Helminths of rodents and marsupials from Papua New Guinea, with the description of two new species, Echinostoma echymiperae n. sp. (Digenea: Echinostomatidae) and Vampirolepis peroryctis n. sp. (Cestoda: Hymenolepididae). Syst Parasitol 1990; 15: 223-237.

24. Georgieva S, Blasco-Costa I, Kostadinova A. Molecular characterization of four echinostomes (Digenea: Echinostomatidae) from birds in New Zealand, with descriptions of Echinostome novaezealandense n. sp. and Echinoparyphium poulini n. sp. Syst Parasitol 2017; 94: 477-497.

25. Kohn A, Fernandes BMM. Sobre as espécies do género Echinos- toma Rudolphi, 1909 descritas por Adolpho Lutz em 1924 Mem Inst Oswaldo Cruz 1975; 73: 77-89.

26. Kostadinova A, Gibson DI. The systematic of the echinostomes. In Fried B, Graczyk TK eds, Echinostomes as Experimental Models for Biological Research. Dordrecht, Boston, London. Kluwer Academic Publishers, Amsterdam, The Netherlands. 2000, pp 31-57.

27. Pinto HA, Melo AL. A checklist of cercariae (Trematoda: Digenea) in mulluscs from Brazil. Zootaxa 2013; 3666: 449-475.

28. Marcó del Pont. Contribución al studio de los zooparásitos de animals salvajes. Semana Méd 1926; 33: 16-22 (in Spanish).

29. Lunaschi L, Cremonte F, Drago FB. Checklist of digenean parasites of birds from Argentina. Zootaxa 2007; 1403: 1-6.

30. Yoshino T, Nakamura S, Endoh D, Onuma M, Osa Y, Teraoka H, Kuwana T, Asakawa M. A helminthological survey of four families of waterfowl (Ardeidae, Rallidae, Scolopacidae and Phalaropodidae) from Hokkaido, Japan. J Yamashina Inst Ornithol 2009; 41: 42-54.

31. Detwiler JT, Bos DH, Minchella DJ. Revealing the secret lives of cryptic species: examining the phylogenetic relationships of echinostome parasites in North America. Mol Phylogenet Evol 2010; 55: 611-620.

32. Skrjabin KI, Bashikirova EI. Family Echinostomatidae Dietz, 1909. In Skrjabin KI ed, Trematodes and Animals and Man. Moscow-Leningrad, Russia, 1956; Vol XI1: 51-930 (in Russian).

33. Kanev I, Vassilev I, Bayssade-Dufour C, Albaret JI, Gassone J. Cercarial chaetotaxy of Echinostoma revolutum (Froelich, 1802) and E. echinatum (Zeder, 1803) (Trematoda, Echinostomatidae). Ann Parasitol Hum Comp 1987; 62: 222-234 (in French).

34. Sloss B, Meece J, Tomano M, Nollen P. The genetic relationships between Echinostoma caproni, E. paraensei, and E. trivolvis as determined by electrophoresis. J Helminthol 1995; 69: 243246.

35. Morgan JA, Blair D. Nuclear rDNA ITS sequence variation in the trematode genus Echinostoma: an aid to establishing relationships within the 37-collar-spine group. Parasitology 1995; 111: 609-615.

36. Kostadinova A, Gibson DI, Biserkow V, Chipev N. A quantitative approach to the evaluation of the morphological variability of two echinostomes, Echinostoma miyagawai Ishii, 1932 and E. revolutum (Froelich, 1802), from Europe. Syst Parasitol 2000; 45: 1-15.

37. Hsu KC, Lie KJ, Basch PF. The life history of Echinostoma rodriguesi sp. n. (Trematoda: Echinostomatidae). J Parasitol 1968; 54: 333-339.

38. Nassi H, Dupouy J. Experimental study of the life history of Echinostoma parvocirrus n. sp. (Trematoda: Echinostomatidae), a larval parasite of Biomphalaria glabrata in Guadeloupe. Ann Parasitol Hum Comp 1988; 63: 103-108 (in French).

39. Toledo R, Muñoz-Antoli C, Esteban JG. The life-cycle of Echinostoma friedi $\mathrm{n}$. sp. (Trematoda: Echinostomatidae) in Spain and a discussion on the relationships within the 'revolutum' group based on cercarial chaetotaxy. Syst Parasitol 2000; 45: 
199-217.

40. Kostadinova A, Herniou EA, Barrett J, Littlewood DTJ. Phylogenetic relationships of Echinostoma Rudolphi, 1809 (Digenea: Echinostomatidae) and related genera re-assessed via DNA and morphological analyses. Syst Parasitol 2003; 54: 159-176.

41. Morgan JA, Blair D. Mitochondrial ND1 gene sequences used to identify echinostome isolates from Australia and New Zealand. Int J Parasitol 1998; 28: 493-502.

42. Detwiler JT, Zajac AM, Minchella DJ, Belden LK. Revealing cryptic parasite diversity in a definitive host: echinostomes in muskrats. J Parasitol 2012; 98: 1148-1155.

43. Kechemir N, Jourdane J, Mas-Coma S. Life cycle of a new African echinostome species reproducing by parthenogenesis. J Nat Hist 2002; 36: 1777-1784.

44. Maldonado Jr A, Vieira GO, Lanfredi RM. Echinostoma luiseryi n. sp. (Platyhelminthes: Digenea) by light and scanning electron microscopy. J Parasitol 2003; 89: 800-808.

45. Georgieva S, Selbach C, Faltýnková A, Soldánová M, Sures B, Skirnisson K, Kostadinova A. New cryptic species of the 'revolutum' group of Echinostoma (Digenea: Echinostomatidae) revealed by molecular and morphological data. Parasit Vectors 2013; 6: 64 .

46. Mohanta UK, Watanabe T, Anisuzzaman, Ohari Y, Itagaki T. Characterization of Echinostoma revolutum and Echinostoma robustum from ducks in Bangladesh based on morphology, nuclear ribosomal ITS2 and mitochondrial nad1 sequences. Parasitol Int 2019; 69: 1-7.

47. Heneberg P. Taxonomic comments on the validity of Echinostoma miyagawai Ishii, 1932 (Trematoda: Echinostomatidae). Parasitol. Int 2020; 74: 101931.

48. Noikong W, Wongsawad C, Chai JY, Saenphet S, Trudgett A. Molecular analysis of echinostome metacercariae from their second intermediate host found in a localised geographic region reveals genetic heterogeneity and possible cryptic speciation. PLoS Negl Trop Dis 2014; 8: e2778.

49. Cho J, Jung BK, Chang T, Sohn WM, Sinuon M, Chai JY. Echinostoma mekongi n. sp. (Digenea: Echinostomatidae) from riparian people along the Mekong River in Cambodia. Korean J Parasitol 2020; 58: 431-443.

50. Lee SH, Sohn WM, Chai JY. Echinostoma revolutum and Echinoparyphium recurvatum recovered from house rats in Yangyanggun, Kangwon-do. Korean J Parasitol 1990; 28: 235-240.

51. Sohn WM, Chai JY, Yong TS, Eom KS, Yoon CH, Sinuon M, Socheat $\mathrm{D}$, Lee SH. Echinostoma revolutum infection in children, Pursat Province, Cambodia. Emerg Infect Dis 2011; 17: 117119.

52. Saijuntha W, Tantrawatpan C, Sithithaworn P, Andrews RH, Petney TN. Genetic characterization of Echinostoma revolutum and Echinoparyphium recurvatum (Trematoda: Echinostomatidae) in Thailand and phylogenetic relationships with other isolates inferred by ITS1 sequence. Parasitol Res 2011; 108: 751755.

53. Saijuntha W, Tantrawatpan C, Sithithaworn P, Andrews RH,
Petney TN. Spatial and temporal genetic variation of Echinostoma revolutum (Trematoda: Echinostomatidae) from Thailand and the Lao PDR. Acta Trop 2011; 118: 105-109.

54. Saijuntha W, Sithithaworn P, Duenngai K, Kiatsopit N, Andrews RH, Petney TN. Genetic variation and relationships of four species of medically important echinostomes (Trematoda: Echinostomatidae) in South-East Asia. Infect Genet Evol 2011; 11: 375-381.

55. Chai JY Sohn WM, Na BK, De NV. Echinostoma revolutum: metacercariae in Filopaludina snails from Nam Dinh Province, Vietnam, and adults from experimental hamsters. Korean J Parasitol 2011; 49: 449-455.

56. Chai JY, Sohn WM, Yong TS, Eom KS, Min DY, Hoang EH, Phammasack B, Insisiengmay B, Rim HJ. Echinostome flukes recovered from humans in Khammouane Province, Lao PDR. Korean J Parasitol 2012; 50: 269-272.

57. Chantima K, Chai JY, Wongsawad C. Echinostoma revolutum: freshwater snails as the second intermediate hosts in Chiang Mai Province, Thailand. Korean J Parasitol 2013; 51: 183-189.

58. Lie KJ, Umathevy T. Studies on Echinostomatidae (Trematoda) in Malaya. VIII. The life history of Echinostoma audyi sp. n. J Parasitol 1965; 51: 781-788.

59. Ando R, Ozaki Y. On four new species of trematodes of the family Echinostomatidae. Dobutsugaku Zasshi 1923; 35: 108119 (in Japanese).

60. Seo BS, Cho SY, Chai JY. Studies on intestinal trematodes in Korea I. A human case of Echinostoma cinetorchis infection with an epidemiological investigation. Seoul J Med 1980; 21: 21-29.

61. Lee SH, Chai JY, Hong ST, Sohn WM. Experimental life history of Echinostoma cinetorchis. Korean J Parasitol 1990; 28: 39-44.

62. Mohandas A. Studies on the life history of Echinostoma ivaniosi n. sp. J Helminthol 1973; 47: 421-438.

63. Sandground JH, Bonne C. Echinostoma lindoensis n. sp., a new parasite of man in the Celebes with an account of its life history and epidemiology. Am J Trop Med Hyg 1940; 20: 511-536.

64. Chu JK, Cho YJ, Chung SB, Won BO, Yoon MB. Study on the trematode parasites of the birds in Korea. Korean J Parasitol 1973; 11: 70-75 (in Korean).

65. Eom KS, Rim HJ, Jang DH. A study on the parasitic helminths of domestic duck (Anas platyrhynchos var. domestica Linnaeus) in Korea. Korean J Parasitol 1984; 22: 215-221.

66. Anisuzzaman, Alim MA, Rahman MH, Mondal MMH. Helminth parasites in indigenous ducks: seasonal dynamics and effects on production performance. J Bangladesh Agricul Univ 2005; 3: 283-290.

67. Memon M, Birmani NA, Shaikh AM, Memon KH. New host record Echinostoma paraulum (Digenea: Echinostomatidae) in house crow (Corrus splendens Vieillot, 1817) of district Khairpur, Sindh, Pakistan. J Entomol Zool Stud 2018; 6: 586-589.

68. Yamaguti S. Studies on the helminth fauna of Japan. Part 3. Avian trematodes, II. Jpn J Zool 1934; 5: 542-583.

69. Kurisu Y. Studies on trematodes which take Japanese house hen as the definitive host. Kumamoto Igakkai Zasshi 1932; 8: 
283-298 (in Japanese).

70. Islam MR, Shaikh H, Baki MA. Prevalence and pathology of helminth parasites in domestic ducks of Bangladesh. Vet Parasitol 1988; 29: 73-77.

71. Rim HJ. Echinostomiasis. CRC Handbook Series in Zoonoses, Section C: Parasitic Zoonoses, Vol. III. Trematode Zoonoses. Boca Raton, USA. CRC Press Inc., 1982, pp 53-69.

72. Nagataki M, Tantrawatpan C, Agatsuma T, Sugiura T, Duenngai K, Sithithaworn P, Andrews RH, Petney TN, Saijuntha W. Mitochondrial DNA sequences of 37 collar-spined echinostomes (Digenea: Echinostomatidae) in Thailand and Lao PDR reveals presence of two species: Echinostoma revolutum and E. miyagawai. Infect Genet Evol 2015; 35: 56-62.

73. Fu YT, Jin JC, Li F, Liu GH. Characterization of the complete mitochondrial genome of the echinostome Echinostoma mixagawai and phylogenetic implications. Parasitol Res 2019; 118: 3091-3097.

74. Li Y, Qiu YY, Zeng MH, Diao PW, Chang QC, Gao Y, Zhang Y, Wang CR. The complete mitochondrial genome of Echinostoma miyagawai: comparisons with closely related species and phylogenetic implications. Infect Genet Evol 2019; 75: 103961.

75. Anucherngchai S, Chontananarth T, Tejangkura T. The study of cytochrome $B($ CYTB): species specific detection and phylogenetic relationship of Echinostoma revolutum (Froelich, 1802). J Parasit Dis 2019; 43: 66-74.

76. Rayski C, Fahmy MAM. Investigation on some trematodes of birds from the East Scotland. Z Parazitenkd 1962; 22: 186-195.

77. Fagasinski A. Helminth parasites of domestic galliform birds in Poland. Acta Parasitol Pol 1962; 10: 347-368 (in Polish).

78. Koltelnikov GA. The biology of Echinostoma robustum Yamaguti, 1935 causing disease in ducks. Sbornik Nauchno-Tekhnich Inform Vsess Inst Ghelmintol KI Skrjabina 1961; 7/8: 29 (in Russian).

79. Alekseev VM. The life cycles of Echinostoma revolutum (Froelish, 1802) and E. robustum Yamaguti, 1935 in the Primorsk Region. Soobshch dal'nevost. Fil. V.L. Komarova sib. Otdel. Akad. Nauk SSSR 1968; 26: 3-7 (in Russian).

80. Richard J. Trematodes d'Oiseaux de Madagascar (Note III). Espèces de la famille Echinostomatidae Poche 1926. Ann Parasitol Hum Comp 1964; 34: 607-620.

81. Richard J, Brygoo ER. Life cycle of the trematode Echinostoma caproni Richard, 1964 (Echinostomatidae). Ann Parasitol Hum Comp 1978; 53: 265-275.

82. Bisseru B. Stages in the development of larval echinostomes recovered from schistosome transmitting molluscs in Central Africa. J Helminthol 1967; 2: 89-108.

83. Jeyarasasingam U, Heyneman D, Lim HK, Mansour N. Life cycle of a new echinostome from Egypt, Echinostome liei sp. nov. (Trematoda: Echinstomatidae). Parasitology 1972; 65: 203222.

84. Jourdane J, Kulo SD. Etude expérimentale du cycle biologique de Echinostoma togoensis n. sp., parasite a l'état larvaire de Biomphalaria pfeifferi au Togo. Ann Parasitol (Paris) 1981; 56: 477-
488.

85. Fried B, Huffman JE. The biology of the intestinal trematode Echinostoma caproni. Adv Parasitol 1996; 38: 311-368.

86. Sorensen RE, Kanev I, Fried B, Minchella DJ. The occurrence and identification of Echinostoma revolutum from North American Lymnaea elodes snails. J Parasitol 1997; 83: 169-170.

87. Sorensen RE, Curtis J, Minchella DJ. Intraspecific variation in the rDNA ITS loci of 37-collar-spined echinostomes from North America: implications for sequence-based diagnoses and phylogenetics. J Parasitol 1998; 84: 992-997.

88. Lutz A. Untersuchung über die Entwicklungsgeschichte brazilianischer Trematoden. Spezieller Teil. I. Echinostomatidae. Mem Inst Oswaldo Cruz 1924; 17: 75-93.

89. Maldonado A Jr, Loker ES, Morgan JAT, Rey L, Lanfredi RM. Description of the adult worms of a new Brazilian isolate of Echinostoma paraensei (Platyhelminthes: Digenea) from its natural vertebrate host Nectomys squamipes by light and scanning electron microscopy and molecular analysis. Parasitol Res 2001; 87: 840-848.

90. Maldonado A Jr, Vieira GO, Garcia JS, Rey L, Lanfredi RM. Biological aspects of a new isolate of Echinostoma paraensei (Trematoda: Echinostomatidae): susceptibility of sympatric snails and the natural vertebrate host. Parasitol Res 2001; 87: 853-859.

91. Brasil MD, Amato SB. Faunistic analysis of the helminths of sparrows (Passer domesticus L, 1758) captured in Campo Grande, Rio de Janeiro, R. J. Mem Inst Oswaldo Cruz 1992; 87: 43-48.

92. Maldonado A Jr, Lanfredi RM. Echinostomes in the wild. In Fried B, Toledo R eds, The Biology of Echinostomes. New York, USA. Springer Science+Business Media, LLC. 2009, pp 129145.

93. Nicoll W. The trematode parasites of North Queensland. II. Parasites of birds. Parasitology 1914; 7: 105-126.

94. Johnson J. The life cycle of Echinostoma revolutum (Froelich). Univ California Public Zool 1920; 19: 335-388.

95. Mendheim H. Beiträge zur Systematik und Biologie der Familie Echinostomatidae (Trematoda). Archiv für Naturgeschichte 1943; 12: 175-302.

96. Bashikirova EI. Family Echinostomatidae Dietz, 1909. In Skrjabin KI ed, Trematodes and Animals and Man. Moscow, Russia. 1947; 1: 310-391.

97. Yamaguti S. Systema Helminthum. Vol. I. The digenetic trematodes of vertebrates (Part I). Interscience Publishers Inc., New York, USA. 1958, pp 1-979.

98. McDonald ME. Key to trematodes reported in waterfowl. US Department of the Interior. Fish and Wildlife Service, Resource Publication 142. Washington DC. 1981, pp. 1-156.

99. Schuster R. Echinostoma echinatum, Notocotylus noyeri and Quinqueserialis quinqueserialis als seltene Parasiten von Rattus norvegicus. Angew Parasitol 1986; 27: 221-225 (in German).

100. Christensen NØ, Fried B, Kanev I. Taxonomy of 37-collar spines Echinostoma (Trematoda: Echinostomatiade) in studies on the population regulation in experimental rodent hosts. Angew Parasitol 1990; 31: 127-130. 
101. Anazawa K. On a human case of Echinostoma revolutum and its infection route. Taiwan Igakkai Zasshi 1929; no. 288: 221-241 (in Japanese).

102. Lu SC. Echinostomiasis in Taiwan. Int J Zoon 1982; 9: 33-38.

103. Bonne C, Bras G, Lie KJ. Five echinostomes in man in the Malayan Archipelago. Am J Dig Dis 1953; 20: 12-16.

104. Radomyos P, Radomyos B, Tungtrongchitr A. Multi-infection with helminths in adults from northeast Thailand as determined by post-treatment fecal examination of adult worms. Trop Med Parasitol 1994; 45: 133-135.

105. Morgan JA, Blair D. Relative merits of nuclear ribosomal internal transcribed spacers and mitochondrial CO1 and ND1 genes for distinguishing among Echinostoma species (Trematoda). Parasitology 1998; 116: 289-297.

106. Leidy J. On the trematodes of the muskrat. Proc Acad Nat Sci Phila 1888; 40: 126.

107. Stiles CW, Hassall A. A new species of intestinal fluke (Distoma tricolor) in the cotton-tail rabbit (Lepus sylvaticus Bachman) and in the northern hare (L. americanus Erxl.); Distoma (Polyorchis) molle (Leidy, 1856) Stiles \& Hassall, 1894. Notes on parasites 29-30. Vet Magaz 1895; 1: 73.

108. Hassall A. Check list of animal parasites of chicken (Gallus domesticus). US Department of Agriculture. Bureau of Animal Industry, Circular 9. 1896, pp 7.

109. Saijuntha W, Sithithaworn P, Andrews RH. Genetic differentiation of Echinostoma revolutum and Hypoderaeum conoideum from domestic ducks in Thailand by multilocus enzyme electrophoresis. J Helminthol 2010; 84: 143-148.

110. Saijuntha W, Tapdara S, Tantrawatpan C. Multilocus enzyme electrophoresis analysis of Echinostoma revolutum and Echinostoma malayanum (Trematoda: Echinostomatidae) isolated from Khon Kaen Province, Thailand. Asian Pac J Trop Med 2010; 3: 633-636.

111. Buddhachat $\mathrm{K}$, Chontananarth $\mathrm{T}$. Is species identification of Echinostoma revolutum using mitochondrial DNA barcoding feasible with high-resolution melting analysis? Parasitol Res 2019; 118: 1799-1810.

112. Le TH, Pham LTK, Doan HTT, Le XTK, Saijuntha W, Rajapakse RPJ, Lawton SP. Comparative mitogenomics of the zoonotic parasite Echinostoma revolutum resolves taxonomic relationships within the 'E. revolutum' species group and the Echinostomata (Platyhelminthes: Digenea). Parasitology 2020; 147: 566-576.

113. Tantrawatpan C, Saijuntha W. Multiplex PCR development for the differential detection of four medically important echinostomes (Trematoda: Echinostomatidae) in Thailand. Acta Trop 2019; 204: 105304.

114. Ishii N. Studies on bird trematodes. I. Bird trematodes in Japan \& II. Four new bird trematodes. Jpn J Exp Med 1932; 11: 91-100.

115. Kosupko GA. Morphological peculiarity of cercariae of Echinostoma revolutum and Echinostoma miyagawai. Trudy vsesoyuznogo Instituta Helminthologii 1969; 15: 159-165 (in Russian).

116. Kosupko GA. Studies on the morphological and biological peculiarity of Echinostoma revolutum (von. Froelich, 1802) and
Echinostoma miyagawai Ishii, 1932 (Trematoda: Echinostomatidae) on experimental material. PhD Thesis, Moscow, Russia. 1972, pp 1-258 (in Russian).

117. Lie KJ, Basch PF. Life history of Echinostoma barbosai sp. n (Trematoda: Echinostomatidae). J Parasitol 1966; 52: 10521057.

118. Mutafova T, Kanev I. Karyotype of an echinostome with features of Echinostoma barbosai Lie and Basch, 1966 (Trematoda: Echinostomatidae) found in Bulgaria. Khelminthologiia 1983; 16: 42-45.

119. Mutafova T, Kanev I. Karyotype and chromosome analysis of collar spined parasitic worms (Trematoda: Echinostomatidae). Abstract in the 5th Nat Conf Parasitol, Varna, Bulgaria. 1987, pp 185.

120. Fernández MV, Hamann MI, Núñez MO. Echinostome cercariae from Biomphalaria straminea (Mollusca: Planorbidae) in a ricefield from northeastern Argentina. Rev Mex Biodiver 2014; 85: 1024-1031.

121. Sianto L, Duarte AN, Borba VH, Magalhães JG, de Souza SM, Chame M. Echinostomes in felid coprolites from Brazil. J Parasitol 2016; 102: 385-387.

122. Nasincova V. The life cycle of Echinostoma bolschewense (Kotova, 1939) (Trematoda: Echinostomatidae). Folia Parasitol 1991; 38: 143-164.

123. Barus V, Moravec F, Rysavy B. Antagonistic interaction between Echinostoma revolutum and Echinoparyphium recurvatum (Trematoda) in the definitive host. Folia Parasitol (Praha) 1974; 21: 155-159.

124. Christensen $\mathrm{N} \varnothing$. Echinostoma revolutum: labelling of miracidia with radioselenium in vivo and assay for host finding. Exp Parasitol 1980; 50: 67-73.

125. Christensen NØ, Fagbemi BO, Nansen P. Trypanosoma bruceiinduced blockage of expulsion of Echinostoma revolutum and of homologous E. revolutum resistance in mice. J Parasitol 1984; 70: 558-561.

126. Christensen NØ, Knudsen J, Fagbemi BO, Nansen P. Impairment of primary expulsion of Echinostoma revolutum in mice concurrently infected with Schistosoma mansoni. J Helminthol 1985; 59: 333-335.

127. Christensen NØ, Knudsen J, Andreassen J. Echinostoma revolutum: resistance to secondary and superimposed infection in mice. Exp Parasitol 1986; 61: 311-318.

128. Christensen NØ, Odaibo AB, Simonsen PE. Echinostoma population regulation in experimental rodent definitive hosts. Parasitol Res 1988; 75: 83-87.

129. Bindseil E, Christensen NØ. Thymus-independent crypt hyperplasia and villous atrophy in the small intestine of mice infected with the trematode Echinostoma revolutum. Parasitology 1984; 88: 431-438.

130. Simonsen PE, Andersen BJ. Echinostoma revolutum in mice: Dynamics of the antibody attack to the surface of an intestinal trematode. Int J Parasitol 1986; 16: 475-482.

131. Sutton CA, Lunaschi L. Contribution to the knowledge of the 
parasite fauna of Argentina. VIII. A new digenean in Chloephaga picta melanoptera Gmelin. Neotropica 1980; 26: 13-17 (in Portuguese).

132. Dollfus PR. Distomens parasites de Muridae du genre Mus. Ann Parasitol (France) 1925; 3: 85-102 (in French).

133. Sugimoto M. On a trematode parasite (Echinostoma cinetorchis Ando and Ozaki, 1923) from a Formosan dog. Nippon Juigakkai Zasshi 1933; 12: 231-236 (in Japanese).

134. Tanabe K, Takeishi H. A survey of helminths in the digestive system of the rat. Keio Igakku 1936; 16: 1767-1785 (in Japanese).

135. Seo BS, Rim HJ, Lee CW. Studies on the parasitic helminths of Korea. I. Trematodes of rodents. Korean J Parasitol 1964; 2: 2026.

136. Seo BS, Cho SY, Hong ST, Hong SJ, Lee SH. Studies on parasitic helminths of Korea. V. Survey on intestinal trematodes of house rats. Korean J Parasitol 1981; 19: 131-136.

137. Cho SY, Kang SY, Ryang YS. Helminthes infections in the small intestine of stray dogs in Ejungbu City, Kyunggi Do, Korea. Korean J Parasitol 1981; 19: 55-59 (in Korean).

138. Takahashi S, Ishii T, Ueno N. A human case of Echinostoma cinetorchis. Tokyo Iji Shinshi 1930; 2757: 141-144 (in Japanese).

139. Takahashi S, Ishii T, Ueno N. The second human case of Echinostoma cinetorchis and a case of tapeworm in a man. Tokyo Iji Shinshi 1930; 2678: 1326-1327 (in Japanese).

140. Kawahara S, Yamamoto E. Human cases of Echinostoma cinetorchis. Tokyo Iji Shinshi 1933; 2840: 1794-1796 (in Japanese).

141. Ryang YS, Ahn YK, Kim WT, Shin KC, Lee KW, Kim TS. Two cases of human infection by Echinostoma cinetorchis. Korean J Parasitol 1986; 24: 71-76 (in Korean).

142. Lee SK, Chung NS, Ko IH, Ko HI, Sohn WM. A case of natural human infection by Echinostoma cinetorchis. Korean J Parasitol 1988; 26: 61-64 (in Korean).

143. Son WY, Huh S, Lee SU, Woo HC, Hong SJ. Intestinal trematode infections in the villagers in Koje-myon, Kochang-gun, Kyongsangnam-do, Korea. Korean J Parasitol 1994; 32: 149155.

144. Jung WT, Lee KJ, Kim HJ, Kim TH, Na BK, Sohn WM. A case of Echinostoma cinetorchis (Trematoda: Echinostomatidae) infection diagnosed by colonoscopy. Korean J Parasitol 2014; 52: 287-290

145. Chai JY, Lee SH. Food-borne intestinal trematode infections in the Republic of Korea. Parasitol Int 2002; 51: 129-154.

146. Chai JY, Shin EH, Lee SH, Rim HJ. Foodborne intestinal flukes in Southeast Asia. Korean J Parasitol 2009; 47 (suppl): 69-102.

147. Anh NTL, Madsen H, Dalsgaard A, Phuong NT, Thanh DTH, Murrell KD. Poultry as reservoir hosts for fishborne zoonotic trematodes in Vietnamese fish farms. Vet Parasitol 2010; 169: 391-394.

148. Toledo R, Esteban JG. An update on human echinostomiasis. Trans R Soc Trop Med Hyg 2016; 110: 37-45.

149. Toledo R, Muñoz-Antoli C, Esteban JG. Intestinal trematode infections. Digenetic Trematodes. Adv Exp Med Biol 2014; 766:
201-240.

150. Toledo R, Radev V, Kanev I, Gardner SL, Fried B. History of echinostomes (Trematoda). Acta Parasitol 2014; 59: 555-567.

151. Kostadinova A. Echinostoma echinatum (Zeder, 1803) sensu Kanev (Digenea: Echinostomatidae): a note of caution. Syst Parasitol 1995; 32: 23-26.

152. Lie KJ. Further studies on the life history of Echinostoma lindoense Sandground and Bonne, 1940 (Trematoda: Echinostomatidae) with a report on its occurrence in Brazil. Proc Helminthol Soc Wash 1968; 35: 74-77.

153. Vasilev I, Kanev I, Shvetlikovski M, Bushta I. Establishment of an echinostome with the features of Echinostoma lindoense Sanground et Bonne (1940) (Echinostomatidae: Trematoda) in Poland and Czechoslovakia. Khelminthologiia 1982; 13: 12-21 (in Bulgarian).

154. Feliu C, Gracenea M, Montoliu I. Torres I. On the finding of Echinostoma lindoense Sandground and Bone, 1940 (Trematoda: Echinostomatidae) in Mus musculus Linnaeus, 1758 (Rodentia; Muridae) of the Ebro Delta (NE of the Iberian Peninsula). Rev Iber Parasitol 1987; 47: 125-126 (in Spanish).

155. Lie KJ. Studies on Echinostomatidae (Trematoda) in Malaya. VII. The life history of Echinostoma lindoense Sandground and Bonne, 1940. Trop Geogr Med 1964; 16: 72-81.

156. Lie KJ, Nasemary S, Impand P. Five echinostome species from Thailand. Southeast Asian J Trop Med Public Health 1973; 4: 96-101.

157. Eduardo SL, Lee GQ. Some zoonotic trematodes from the Philippine field rat, Rattus mindanensis mindanensis (Mearns, 1905) (Mammalia: Rodentia) in Bay, Laguna, Philippines with description and new records of species. Phil J Vet Med 2006; 43: 33-45.

158. Lie KJ, Kanev I. Identification and distribution of Echinostoma lindoense, E. audyi and E. revolutum (Trematoda: Echinostomatidae). Z Parasikenkd 1983; 69: 223-227.

159. Simões RO, Souza JGR, Maldonado Jr A, Luque JL. Variation in the helminth community structure of three sympatric sigmodontine rodents from the coastal Atlantic Forest of Rio de Janeiro, Brazil. J Helminthol 2011; 85: 171-178.

160. Sianto L, Reinhard KJ, Chame M, Chaves S, Mendonça S, Gonçalves MLC, Fernandes A, Ferreira LF, Araújo A. The finding of Echinostoma (Trematoda: Digenea) and hookworm eggs in coprolites collected from a Brazilian mummified body dated 600-1,200 years before present. J Parasitol 2005; 91: 972-975.

161. Cooper CL. The helminth parasites of an insular avian passerine community: relationship to landscape epidemiology. Ph.D. Dissertation to Ohio State University, USA. 1975, pp 1-209.

162. Kostadinova A. Cercarial chaetotaxy of Echinostoma miyagawai Ishii, 1932 (Digenea: Echinostomatidae), with a review of the sensory patterns in the 'revolutum' group. Syst Parasitol 1999; 44: 201-209.

163. Uchida A, Uchida K, Kawakami Y, Nagatomo M, Shen M, Ooi HK. A helminthological survey of parasites in the waterfowl of Kanagawa prefecture. J Jpn Vet Med Assoc 2005; 58: 127-131 (in Japanese). 
164. Haziev GZ, Khan SA. Helminths of guinea fowl (Numida meleagris) in Bashkir ASSR. Vet Parasitol 1991; 38: 349-353.

165. Schou TW, Permin A, Juul-Madsen HR, Sørensen P, Labouriau R, Nguyên TLH, Fink M, Pham SL. Gastrointestinal helminths in indigenous and exotic chickens in Vietnam: association of the intensity of infection with the major histocompatibility complex. Parasitology 2007; 134: 561-573.

166. Faltýnková A, Našincová V, Kablásková L. Larval trematodes (Digenea) of planorbid snails (Gastropoda: Pulmonata) in Central Europe: a survey of species and key to their identification. Syst Parasitol 2008; 69: 155-178.

167. Kavetska KM, Rzad I, Kornyushin VV, Korol EN, Sitko J, Szatanska K. Enteric helminths of the mallard Anas platyrhynchos L., 1758 in the north-western part of Poland. Wiadom Parazitol 2008; 54: 23-29 (in Polish).

168. Nasincova V. Contribution to the distribution and the life history of Echinostoma revolutum (Trematoda) in Central Europe. Vestnik Ceskoslovenske Spolecnosti Zool 1986; 50: 70-80.

169. Schwelm J, Soldánová M, Vyhlidalová T, Sures B, Selbach C. Small but diverse: larval trematode communities in the small freshwater planorbids Gyraulus albus and Segmentina nitida (Gastropoda: Pulmonata) from the Ruhr River, Germany. Parasitol Res 2017; 117: 241-255.

170. McKenna PB. Additions to the checklists of helminth and protozoan parasites of terrestrial mammals and birds in New Zealand. NZ J Zool 2018; 45: 395-401.

171. Nasir P. Studies on the life history of Echinostoma nudicaudatum $\mathrm{n}$. sp. (Echinostomatidae: Trematoda). J Parasitol 1960; 46: 833847.

172. Nasir P. Further observations on the life cycle of Echinostoma nudicaudatum Nasir, 1960 (Echinostomatidae: Trematoda). Proc Helminthol Soc Wash 1962; 29: 115-127.

173. O’Dwyer K, Poulin R. Taken to the limit-Is desiccation stress causing precocious encystment of trematode parasites in snails? Parasitol Int 2015; 64: 632-637.

174. Nasir P. Observations on the life cycle of Echinostoma pinnicaudatum n. sp. (Echinostomatidae: Trematoda). Proc Helminthol Soc Wash 1961; 28: 207-212.

175. Nasir P, Erasmus DA. A key to the cercariae from British freshwater molluscs. J Helminthol 1964; 38: 245-268.

176. Lie KJ, Basch PF. The life history of Echinostoma paraensei sp. n (Trematoda: Echinostomatidae). J Parasitol 1967; 53: 11921199.

177. Petrie JL, Burg EF III, Cain GD. Molecular characterization of Echinostoma caproni and E. paraensei by random amplification of polymorphic DNA (RAPD) analysis. J Parasitol 1996; 82: 360-362.
178. Meece JK, Nollen PM. A comparison of the adult and miracidial stages of Echinostoma paraensei and E. caproni. Int J Parasitol 1996; 26: 37-43.

179. Fried B, Reddy A. Comparative studies on excystation and morphological features of the metacercariae of Echinostoma paraensei and E. caproni. Int J Parasitol 1997; 27: 899-901.

180. Miller MJ. The parasites of pigeons in Canada. Can J Res 1937; 15: 91-103.

181. Skrjabin KI. Echinostoma paraulum-nouveau parasite de l'homme. Med Parazitol Parazitarn Bolezni 1938; 7: 129-138 (in Russian).

182. Supperer R. Untersuchungen über Parasiten der Hausente, Anas platyrhynchos Dom. Z Parasitenkd 1959; 19: 259-277 (in German).

183. Skrjabin KI. Trematodes dans les oiseaux d'Oural. Ann Muz Zool Acad Sci St.-Petersburg, 1915; 20: 395-417 (in Russian).

184. Sprehn C. Echinostomiden bei Tauben. Deutsche tierärztl. Wochenschr 1927; 25: $451-455$ (in German).

185. Iskova NI. Trematoda. Vol. 4. Echinostomes. Kiev: Naukova Dumka. Fauna Ukrainy 1985; 34: 1-198 (in Russian).

186. Uchida A, Uchida K, Itagaki H, Kamegai S. Checklist of helminth parasites of Japanese birds. Jpn J Parasitol 1991; 40: 7-85.

187. Yamaguti S. Studies on the helminth fauna of Japan. Part 5. Trematodes of birds, III. Jpn J Zool 1935; 6: 159-182.

188. Yang G, Di S. Reviews on the trematodes of poultry in China. J Sichuan Agricul Univ. 1999; 17: 85-89 (in Chinese).

189. Lunaschi L, Drago FB. Checklist of digenean parasites of wild mammals from Argentina. Zootaxa 2007; 1580: 35-50.

190. Lunaschi L, Drago FB, Núñez V. Two new species of Echinostoma (Digenea: Echinostomatidae) from Argentinean birds. Rev Mex Biodivers 2018; 89: 356-364 (in Spanish).

191. Pinto HA, Melo AL. Physa marmorata (Mollusca: Physidae) as intermediate host of Echinostoma exile (Trematoda: Echinostomatidae) in Brazil. Neotrop Helminthol 2012; 6: 291-299 (in Portuguese).

192. Cort WW. Larval trematodes from North American fresh-water snails. J Parasitol 1914; 1: 65-84.

193. Cort WW. Some North American larval trematodes. Illin Biol Monogr 1915; 1: 447-532.

194. Barker FD. Parasites of the American muskrat (Fiber zibethicus). J Parasitol 1915; 1: 184-197.

195. Law RG, Kennedy AH. Parasites of fur-bearing animals. Bull Dept Game Fisher, Ontario, Canada 1932; 4: 1-30.

196. Miller EL. Studies on North American cercariae. Illin Biol Monogr 1936; 14: 1-125.

197. Dimitrov V, Kanev I, Fried B, Radev V. Sensilla of the cercariae of Echinostoma trivolvis (Cort, 1914) (Trematoda: Echinostomatidae). Parasite 1997; 2: 153-158. 
